\section{UKCPR}

University of Kentucky

Center for

\section{Discussion Paper Series}

DP 2012-13

\title{
Multigenerational Families and Food Insecurity
}

\author{
James P. Ziliak* \\ Center for Poverty Research \\ Department of Economics \\ University of Kentucky

\section{Craig Gundersen} \\ Department of Agricultural and Consumer Economics \\ University of Illinois
}

November, 2012

Preferred citation

Ziliak, James P., \& Gundersen, Craig. Multigenerational Families and Food Insecurity. University of Kentucky Center for Poverty Research Discussion Paper Series, DP2012-13. Retrieved [Date] from http://www. ukcpr.org/Publications/DP2012-13.pdf.

\section{Author correspondence}

*Address correspondence to James P. Ziliak, jziliak@uky.edu or Craig Gundersen, cggunder@illinois.edu. Funding for this research was made possible by a generous grant from the Merck Foundation. We benefited from the research assistance of Sarah Burns, and from the comments of Cynthia Osborne, and seminar participants at the 2012 Population Association of America Meetings and the University of Washington. The conclusions and opinions expressed herein are our own and do not necessarily represent the views of the sponsoring agency. 


\begin{abstract}
The prevalence of multigenerational families is on the rise in the United States, as is food insecurity. We estimate the effect of resident grandchildren on the risk of and transitions in food insecurity using repeated cross sections and longitudinally linked two-year panels of the Current Population Survey from 2001-2010. We find that rates of food insecurity in families with a grandchild present are at least twice as high in a typical year compared to families without a resident grandchild, and the extent of very low food security increased substantially faster among these households over the past decade. The rise in food insecurity during and after the Great Recession is due to both increased entry into food insecurity and decreased exit out of food insecurity. A similar trend accounts for the rise in multigenerational households during the recession-grandchildren were more likely to move in with their grandparents, and once there, were less likely to move out. There are also important differences in risk factors for food insecurity between multigenerational families and those with no grandchildren present. Our transition models show that whether grandchildren remain, or in periods of transition, multigenerational families are at heighted risk of entering food insecurity and remaining in this state. However, the entry of a grandchild may not always be a negative for the family's food security, nor the exit of the child a positive. Entrance of a child seems to buffer the family from extreme forms of food insecurity while exit exposes the family to risk of deeper food insecurity.
\end{abstract}


The prevalence of multigenerational families is on the rise in the United States. From 1980 to 2008, the number of Americans living with at least two adult generations, or a grandparent with another generation, increased by one-third to 49 million (Taylor, et al. 2010). This includes one in five single mother families. Given that over this period the fraction of children born to unwed mothers rose from about 15 percent of live births to nearly 40 percent, there is likely to be continued upward secular pressure on the proportion of families that are multigenerational (Cancian and Reed 2009). On top of the secular trends, the Great Recession has resulted in substantially weakened financial balance sheets, and thus many families have pooled generations to help make ends meet, especially those families headed by an older adult (Taylor, et al. 2010).

Alongside this increase in multigenerational families, food insecurity has emerged as a pressing public health challenge facing the nation. The health consequences associated with food insecurity are manifest in children (Carmichael et al., 2007; Cook et al., 2006; Eicher-Miller et al., 2009; Heflin et al., 2005; Howard, 2011; Huang et al., 2010; Kirkpatrick et al., 2010; Muirhead et al., 2009; Siefert et al., 2004; Skalicky et al., 2006; Whitaker et al., 2006) and adults (Kirkpatrick and Tarasuk. 2007; Lee and Frongillo, 2001; McIntyre et al., 2003; Seligman et al., 2007; Seligman et al., 2009; Stuff et al., 2004; Tarasuk 2001; Ziliak et al., 2008). The health consequences are even more serious in light of the recent increase in food insecurity: after holding steady at about 11 percent of households from 1999 to 2006, food insecurity accelerated over 30 percent after the onset of the recession to encompass 14.5 percent of all households by 2010 (Coleman-Jensen, et al. 2011), suggesting that health problems are likely to be exacerbated in coming years. 
Despite the burgeoning literature on food insecurity in the United States (for a recent review see Gundersen et al., 2011), there has not been research on the level of food insecurity nor on transitions into and out of food insecurity among multigenerational families. We fill this gap in the literature through the use of data from the Current Population Survey (CPS) to present the first evidence on food insecurity in adult households with and without grandchildren present. For our purposes, a multigenerational family is defined as one headed by an adult householder age 40 or older and with three generations (grandparent, parent, child) or grandparent and grandchild with no adult parent (so-called skipped generation). While most adults in their 40s are not grandparents, low-income adults in this age category are over-represented in the population of grandparents and thus potentially at heightened risk of food insecurity. Limiting our sample to seniors over the age of 50 or even 60 would miss this vulnerable group of young grandparents raising grandchildren.

We begin our analysis by pooling repeated cross sections of the CPS from 2001 to 2010 to compare trends in and determinants of food insecurity between multigenerational families and those with no grandchild present in the household. The objective of this section is twofold. First, we identify the magnitude of the difference in food insecurity between multigenerational households and households with no grandchildren present. We consider this with and without controls for confounding factors. Second, we want to identify whether the determining factors of food insecurity (e.g. age, education, income, race, gender) differ in a substantive way between multigenerational households and households with no grandchildren present. Knowledge of whether differences exist will inform policy of whether potential avenues for intervention to alleviate hunger risk need to be catered to different family structures. 
Our next set of analyses exploit a little utilized feature of the CPS that permits the matching of the same individual from one December survey to the following to create a series of two-year panels. A few have examined food insecurity in a panel-data setting (Nord and Wilde 2005; Heflin and Ziliak 2008; Mykerezi and Mills 2010), but none have examined the role of grandchildren in accounting for food insecurity transitions. With the panels we document transitions in food security status among adult households with and without grandchildren present. We also formally estimate transition models as a function of macroeconomic and demographic risk factors, including the entrance and exit of grandchildren.

Our results show that in a typical year rates of food insecurity among multigenerational families are at least twice as high as families without resident grandchildren. By 2010, after the sharp increase due to the Great Recession, food insecurity affected 23 percent of multigenerational families as compared to 11 percent of other families. The rise in food insecurity during and after the Great Recession is due to both increased entry into food insecurity and decreased exit out of food insecurity. A similar trend accounts for the rise in multigenerational households during the recession—grandchildren were more likely to move in with their grandparents, and once there, were less likely to move out.

The multivariate analyses show the strong protective factor of income against risk of food insecurity, especially in multigenerational families. We find that a family in poverty is nearly 10 percentage points more likely to enter food insecurity than a family not in poverty. Likewise, a poor family has a nearly 20 percentage point reduction in the probability of exit into food security. Controlling for poverty status and other risk factors, African Americans and Hispanics are significantly more likely to be food insecure. They are also much more likely to enter food insecurity than similarly situated white families. But interestingly, they are actually more likely 
to exit food insecurity to food security (by 2.6 and 5.1 percentage points, respectively). This suggests that there is more churning in and out of food security among African-Americans and Hispanics than whites. The estimates also suggest that whether grandchildren remain, or in periods of transition, multigenerational households are at heighted risk of entering food insecurity and remaining in this state. However, the entry of a grandchild may not always be a negative for the family's food security, nor the exit of a grandchild a positive. Entrance of a grandchild seems to buffer the family from extreme forms of food insecurity, most likely owing to the fact that additional resources, whether transfers from the social safety net or from other relatives, may flow into the family when the grandchild arrives, and flow out when the child departs.

\section{Trends in Multigenerational Families and Food Insecurity}

The data for our analyses on multigenerational families and food insecurity comes from the December supplements of the CPS spanning the 2001 through 2010 calendar years. The CPS is a nationally representative survey conducted by the Census Bureau for the Bureau of Labor Statistics, providing employment, income and poverty statistics. Households are selected to be representative of civilian households at the state and national levels, and thus do not include information on individuals living in group quarters including nursing homes or assisted living facilities. In December of each year, 50,000 households respond to a series of 18 questions (10 if there are no children present) that make up the Core Food Security Module (CFSM), in addition to questions about food spending and the use of government and community food assistance programs. The CFSM in the CPS is the official data employed by the U.S. Department of Agriculture (USDA) to estimate food insecurity rates annually in the general population. Examples of questions include: "I worried whether our food would run out before we got money 
to buy more,” (the least severe item); “Did you or the other adults in your household ever cut the size of your meals or skip meals because there wasn’t enough money for food?”; “Were you ever hungry but did not eat because you couldn’t afford enough food?”; and “Did a child in the household ever not eat for a full day because you couldn’t afford enough food?” (the most severe item for households with children). Each question is qualified by the stipulation that the outcomes are due to financial issues.

We use the nomenclature of the USDA and consider in this paper four mutually exclusive characterizations of food security: fully food secure (FFS), marginally food secure (MFS), low food secure (LFS), and very low food secure (VLFS). To be fully food secure the respondent answers no to all questions on the CFSM; to be marginally food secure they must answer yes to one or two questions; to be low food secure they must answer yes to 3-5 questions (3-7 questions if children are living in the household); and to be very low food secure they must answer yes to 6 or more questions (8 or more if children are living in the household). ${ }^{1}$ For several of our analyses we instead focus on the non-mutually exclusive categories of marginally food insecure (MFI), which comprises MFS, LFS, and VLFS, and food insecure (FI), which comprises LFS and VLFS.

We assemble two datasets with the CPS—one a pooled cross-section and the second a series of two year panels. For both samples we focus on adult heads of household age 40 and older. In order to be classified as multigenerational there must be a grandchild living in the household, with or without the child’s parent. All other family types (married/unmarried, children/no children) are classified as single or dual-generation families.

The CPS employs a rotating survey design so that a respondent is in sample for 4 months, out 8 months, and in another 4 months. This makes it possible to match approximately one-half

\footnotetext{
${ }^{1}$ A listing of the questions can be found in Appendix Table 1.
} 
of the sample from one December interview to the next. For the pooled cross sections, to ensure that no household is included more than once, the sample includes households observed for the second time in 2001 through 2010. This results in a pooled sample of 263,790 families between the ages of 40 and 90.

For the two-year panels, we follow recommended Census procedure by performing an initial match of individuals on the basis of five variables: month in sample (months 1-4 for year 1, months 5-8 for year 2); gender; line number (unique person identifier); household identifier; and household number. We then cross check the initial match on three additional criteria: race, state of residence, and age of the individual. If the race or state of residence of the person changed we delete that observation, and if the age of the person falls or increases by more than two years (owing to the staggered timing of the initial and final interviews), then we delete those observations on the assumption that they were bad matches.

We note that the sampling frame of the CPS is a household address, and not a household. Thus, if a family moves from one year to the next they are not followed and thus are not matched. If the decision to move is correlated with food insecurity (our dependent variable) then there might be some concerns about consistency of our estimates. However, if moving is a function of observed covariates (i.e. selection on observables) then our multivariate models that control for these confounding factors will be consistent under the missing conditional at random assumption (Bollinger and Hirsch, forthcoming). If moving is also a function of unobservables (i.e. selection on unobservables), but these factors are time-variant, then our transition models that focus on changes in food insecurity should sweep out this potential form of attrition bias (Wooldridge 2002). The resulting series of two-year panels we use contains 163,777 unique longitudinal matches. 


\section{A. Prevalence}

Table 1 contains weighted averages of selected characteristics for the whole sample and by presence of grandchildren. The weight used in all analyses is the supplemental person weight provided in the December CPS survey and is used to adjust the averages to reflect the whole population age 40 and over. Among all adults, about 8 percent are poor and 14 percent have incomes between 100 and $200 \%$ of the poverty line. The majority, though, have incomes above 200\% of the poverty line. Most adults are white, married, a homeowner, live in a metro area, are employed or retired, and have a high school diploma or more.

In a typical year about 4.2 percent of adult households have a grandchild living in the home. Of those, about three-fourths are made up of three generations (grandparent, adult child, and grandchild) and the other fourth are households with only the grandparent and grandchild present. ${ }^{2}$ A comparison of columns (2) and (3) in Table 1 shows that there are substantive differences in the demographics of adult households without and with grandchildren present, and with few exceptions, these differences are statistically significant at the 5 percent level. For example, of those reporting incomes, 55 percent of households with a grandchild live below $200 \%$ of the poverty line compared to 27 percent with no grandchild present. Households with grandchildren are more likely to be African American, to be Hispanic, to live in the South, to be ages 55-65, to be a high school dropout, to be disabled or otherwise out of the labor force, to receive food stamps, and to have a woman as survey respondent. ${ }^{3}$

\footnotetext{
${ }^{2}$ All cases of households where there is a grandparent(s) and a grandchild(ren) but no parent present are obviously cases of a grandparent raising a grandchild. In contrast, we do not know in cases where there are grandparents, parents, and children present if the parents are caring for the grandparent, the grandparent is caring for the child because the parent can't do so, etc.

${ }^{3}$ We also considered two additional splits of the multigenerational families, one where we considered those with an adult parent present (i.e. at least three generations) versus those with a skipped generation (i.e. grandparent and grandchild only), and one where we considered single grandchild families versus those with multiple grandchildren. Both are motivated by the presumption that skipped generation families and those with multiple grandchildren are each at greater risk of food insecurity than three generation families or those with one grandchild, respectively.
} 
Figure 1 depicts trends in the fraction of households headed by an adult with a grandchild present overall and by race. The figure shows that there has been growth of about $19 \%$ in the fraction of multigenerational families 40 and older from 4.1\% in 2001 to $4.8 \%$ in 2010, albeit this is growth on a relatively small base. There is a significant racial gap in the percent of families with a grandchild in that African American households are 2-3 times more likely to have a grandchild present than whites. Moreover, after falling in the early part of the decade, there has been a strong upward trend since the start of the Great Recession in 2007 in African American multigenerational households (an increase of nearly 30\% from 2007 to 2010; the corresponding increase was $22 \%$ among white households). Figure 2 demonstrates that in any given year the percentage of adult households with grandchildren present are significantly more likely to have incomes below the poverty line (<=100\% FPL)). The growth over the decade in the fraction of multigenerational families was also fastest among the poor (about 33\% increase), but the rate among those with income above $200 \%$ of the poverty line also increased by nearly one-quarter. $^{4}$

Turning to figures depicting food insecurity rates over time, Figure 3 depicts trends in food insecurity rates from 2001 to 2010 for all adults age 40 and older in the United States. As seen in the last three rows of Table 1 , on average 15.7 percent are marginally food insecure, 8.9 percent are food insecure, and 3.2 percent are very low food secure. The rates were fairly stable throughout the first half of the decade and then increased dramatically between 2007 and 2008 to

\footnotetext{
Indeed we find that skipped generation families are more likely to be poor, to be African American, to be nonHispanic, to live in nonmetro areas and the South, and to be a high school dropout. However, there was no qualitative or statistical difference in food insecurity. We find a similar result that families with multiple grandchildren have lower socioeconomic status than families with a sole grandchild, but also that there is a qualitative and statistical difference in rates of food insecurity. However, because of concerns over small samples among these sample splits, especially for the transition models, we pool these groups together for our analyses.

${ }^{4}$ In results not tabulated we also found that rates of multigenerational families were inversely related to the education attainment of the family head. However, over the past decade the growth in multigenerational families has been fastest among adult heads with more than high school (34\% compared to $18 \%$ for high school drop outs).
} 
19.1, 10.9, and 4.5 percent, respectively. By the end of the decade, 40 percent more adults age 40 and older were marginally food insecure, 48 percent more were food insecure, and 67 percent more were very low food secure.

In Figure 4 we show trends in food insecurity by the absence or presence of grandchildren in the household. Given their preponderance in the adult population, it is not surprising that the trends facing households with no grandchild present mirror the overall trends. In contrast, rates of marginal food insecurity, food insecurity, and very low food security in households with a grandchild present are generally at least 2 times higher in a typical year. Specifically, if no grandchild is present the average rates across the decade are 14.9, 8.5, and 3.1 percent, respectively, while with a grandchild present the corresponding rates are 32.5, 19.2, and 5.6 percent. Although the overall percentage increase for those facing food insecurity are similar across households with and without grandchildren, the trends followed slightly different paths. For example, families living with grandchildren actually saw a modest decline in food insecurity rates in the years leading up to the Great Recession, whereas rates were stable in families with no grandchildren present. While both groups experienced large increases after 2007, the postrecession trends differed as well. After an increase in very low food security of $125 \%$ between 2007 and 2008 in multigenerational families, the rates fell over the next two years but were still 53 percent higher than in 2007. These trends suggest that the level and trend of food hardship facing adult households poses a serious public policy challenge, and multigenerational households are at even greater risk.

\section{B. Transitions}

Table 2 presents simple transition probabilities across the four mutually exclusive categories from the matched CPS panels. The rows of the table show the food security status of the family in year 1 of the survey, while the columns show the year 2 food security status 
conditional on year 1 . This means that across columns in each row the probabilities sum to 1. We present estimates for the full sample, and by presence of grandchild in year 1, year 2, both years, or neither year. In our matched CPS sample, 3 percent of families have grandchildren living in the home in both years, and 1 percent have children entering or exiting between years 1 and 2.

In the first panel of Table 2 pertaining to the sample as a whole, 93 percent of those age 40 and older who are fully food secure in year 1 are fully food secure in year 2. At the other end, 40 percent of those who are very low food secure in year 1 remain in that status in year 2 . In general as we move down the table we see that the two-year boundary cases of FFS-FFS and VLFS-VLFS have the highest probabilities. The exception is that a substantial fraction move from MFS or LFS in year 1 to FFS in year 2, suggesting that exit from food insecurity is a regular occurrence. At the same token, a nontrivial proportion of adults experience worsening of food security - 9 percent of FFS in year 1 are in some food insecurity category in year 2; 18 percent of MFS in year 1 end up in either LFS or VLS in year 2; and 12 percent of LFS in year 1 transition to VLFS in year 2.

There are some important distinctions across family structure in the food security transition rates in Table 2. Comparing the sample with no grandchildren present in either year to those with a grandchild in one or both years it is clear that the probability of being FFS in both years with a grandchild present is much lower. In addition, multigenerational families are less likely to move from some level of food insecurity to fully food secure (though rates of moving from VLFS to FFS do not differ substantively except for families with the grandchild in year 1 only). However, it does appear that there is more churning across categories in multigenerational families than among those with no grandchild present. 
At any given point in time, the nation's food insecurity rate is a function of the prior period's food insecurity rate along with flows into and out of food insecurity. A similar characterization holds for the proportion of the population that is in multigenerational families. To examine whether the increase in food insecurity and in multigenerational families is a result of increased entry or reduced exit, in Figures 5 and 6 we present entry rates and exit rates for each outcome. In Figure 5 the entry rate into marginal food insecurity (MFI) is computed as the probability of being marginally food insecure in year 2 conditional on being fully food secure in year 1 . The exit rate is thus the probability of being fully food secure in year 2 conditional on being marginally food insecure in year 1. Because the baselines used to compute entry and exit differ, the rates differ significantly and thus are shown on separate axes.

Figure 5 shows that after 2007 there was a significant increase in entry into food insecurity, coupled with a decline in exit rates, which has the dual effects of maintaining the elevated levels of food insecurity. Figure 6, on the other hand, depicts a spike in both entry and exit rates between 2007 and 2008, followed by reduced entry and exit after 2008. Because the exit rate fell faster, and by 2010 was lower than the 2007 value, while the 2010 entry rate remained above the 2007 rate, the overall rate of multigenerational families remained elevated in the aftermath of the Great Recession.

\section{Family Structure and the Determinants of Food Insecurity}

In this section we assess the effect of multigenerational families on the prevalence of food insecurity holding constant other confounding factors, and in the next section we examine the determinants of food insecurity transitions. We first identify the magnitude of difference in food insecurity rates that multigenerational families face relative to households with no grandchildren present after we control for income and other factors. We also identify whether 
the determining factors of food insecurity differ in a substantive way between multi-generation households and households with no grandchild present. Knowledge of whether differences exist will inform policy and research of whether potential avenues for intervention to alleviate hunger risk need to be catered to different family structures.

Specifically we estimate the following models for food insecurity:

$$
F I_{i j}=X_{i j} \beta_{j}+u_{i j}
$$

where $i$ denotes a family and $j=g, n g$ denotes whether the grandchild is present in the household $(g)$ or not $(n g)$; FI is a variable that takes a value of 1 if the person is in a food insecure household (we alternatively use marginally food insecure, food insecure, and very low food secure), $\boldsymbol{X}$ is a vector of potential determinants of food insecurity available in the CPS as presented in Table 1 (e.g., income, race, Hispanic ethnicity, gender, marital status, employment status, homeownership status, age, region); and $u$ is an error term. We assume that the error term $u$ is distributed standard normal and we apply probit maximum likelihood methods.

Our central interest is in the direction, significance, and magnitude of the coefficients on the demographic factors in $\boldsymbol{X}$. Appendix Table 2 lists the various demographic factors included in the regression model. All of the determinants are represented as a series of indicators, and thus there is an omitted group for each set. To test whether or not the factors determining food insecurity differ in multigenerational families we estimate the models in (1) for families with a grandparent and grandchild present, and for those with no grandchild present. We then compare the magnitude and direction of coefficients across the models, and also conduct a formal Wald test to examine whether the coefficients differ statistically. ${ }^{5}$

\section{A. Demographic Factors and the Risk of Hunger}

\footnotetext{
${ }^{5}$ Let $\beta^{g}$ denote the vector of parameters from sample with grandkids present and $\beta^{\text {ng }}$ the corresponding vector for the no grandkids sample. The Wald test of structural change is $\left(\beta^{g}-\beta^{n g}\right)^{\prime}\left[\operatorname{Var}\left(\beta^{g}\right)+\operatorname{Var}\left(\beta^{n g}\right)\right]^{-1}\left(\beta^{g}-\right.$ $\left.\beta^{n g}\right) \sim \chi_{p}^{2}$, which is distributed asymptotic chi-squared with $p$ degrees of freedom (Wooldridge 2002).
} 
Tables 3-5 present the results of models of the determinants of marginal food insecurity, food insecurity, and very low food security, respectively. In columns (1) and (2), the results are for households with grandchildren and in columns (3) and (4), the results are for households without grandchildren present. In addition to the demographic factors listed in Appendix Table 2, all models also control for year-specific influences. ${ }^{6}$ For each specification we present both the coefficients from the probit model of equation (1) along with the so-called marginal effects. The coefficients tell us the direction of association (positive or negative) between a variable and the probability of food insecurity, while the marginal effects tell us the magnitude and direction of a one-unit change in the respective variable on the probability of food insecurity. For example, in the Table 3 specification with no grandchildren the positive coefficient of 0.343 on African American indicates that being African American increases the probability of being marginally food insecure relative to a white person, while the marginal effect of 0.062 implies that an African American is 6.2 percentage points more likely to be marginally food insecure relative to a white person holding other factors constant.

Beginning with the results for marginal food insecurity in Table 3 we see that those households with no grandchildren facing greater risk of marginal food insecurity include nonwhites, Hispanics, high school dropouts, widowed/divorced/separated, 40-64 year olds, the poor, renters, the disabled and unemployed, and those with other people living in the household. Several of the same patterns of effects hold for households with grandchildren present, although there are some important distinctions. First, there is no evidence of a declining age gradient in risk of marginal food insecurity for families with grandchildren present. This was a prominent

\footnotetext{
${ }^{6}$ We also estimated models with state fixed effects, which are intended to capture not readily observable statespecific influences on rates of food insecurity that do not vary over time. We do not include these in the main models of the text because the comparatively small within-state samples of grandchild-present households creates less precise identification of parameters, i.e. some state's observations get dropped because all are food secure. However, the results are qualitatively similar whether state effects are included or not.
} 
result of Ziliak et al. (2008) for a more limited sample of adults age 60 and older, and it does hold in the 40+ sample with no grandchildren present in columns (3) and (4). For example, a 6569 year old is 6 percentage points less likely to be marginally food insecure than a 40-44 year old, and an 80 year old is 10.9 percentage points less likely. On a baseline average rate of 14.96 percent, these marginal effects are sizable, ranging from 40 percent to 70 percent of baseline. However, among multigenerational families there is in general no statistically significant effect of age on the risk of food insecurity.

Second, the food security “disadvantage” of certain demographic characteristics is less when grandchildren are present. For example, being an African American increases the probability of marginal food insecurity by over 40 percent from the baseline mean for families with no grandchildren present, but this effect is just 16 percent when grandchildren are present (the marginal effect of 0.051 in Table 3 compared to the mean of 0.325 in Table 1 ). Third, the food security “advantage” of certain economic factors is more prevalent among families with grandchildren, most notable of these is the strong protective effect of having incomes above the poverty line and especially over twice the line. It is because of these distinctions that the Wald test formally rejects the hypothesis that the coefficients on the determinants affecting marginal food insecurity are the same between families with and without grandchildren present (p-value < $0.000)^{7}$

Tables 4 and 5 contain the set of regression coefficients and marginal effects for the probability of food insecurity and of very low food security, respectively. The pattern of results

\footnotetext{
${ }^{7}$ As mentioned in footnote 3 we also split the grandchild present sample into skipped generations and those with at least three generations, and for families with one grandchild versus multiple grandchildren. In both cases, the Wald test formally rejects that the coefficients are the same, but the test statistic is just 58 (66 for the model based on number of grandkids) with 31 degrees of freedom, compared to 180 in Table 3, and qualitatively they are much more similar to each other than to families with no grandchildren present. One difference is that we find evidence of an age gradient in the model with one grandchild similar to the no grandchild case, suggesting that result in Table 3 of no age gradient in multigenerational families is driven by those families with more than one grandchild present.
} 
is quite similar to those found in Table 3, though as expected the quantitative magnitude of marginal effects are smaller since the probability of being food insecure or very low food secure is considerably lower than being marginally food insecure. Being disabled was seen to raise the probability of marginal food insecurity, and this is true of food insecurity too, but in Table 5 we see that disability has no additional risk for multigenerational household food insecurity. Conditional on income, race, and other covariates, previous analyses in Ziliak, et al. (2008) have found little difference between residents in a metro area versus non-metro for any of the three levels of food insecurity. However, Table 5 shows that living in a metro area substantially increases the probability of very low food security, especially among families with a grandchild present. For the latter the protective effect of living in a non-metro area is comparable in magnitude to having income between 50 and 100 percent of poverty instead of below half the poverty line.

\section{B. Risk Profiles of Food Insecurity}

To help characterize demographic risk profiles of marginal food insecurity, food insecurity, and very low food security for multigenerational families compared to those adult households with no grandchildren present, in Table 6 we present hypothetical predicted probabilities using data from the 2001 to 2010 CPS. Specifically we use the probit regression coefficients in Tables 3-5 to predict the probability of food insecurity based on certain demographic characteristics, namely how the risk of food insecurity varies by presence of grandchildren and by level of family income.

The first profile is of an who is white, employed, married, ages 60-64, college educated, and living in a metropolitan region. We chose this set of traits because we expect them to be a relatively low risk group for food insecurity. We pool the data across years, regions, and gender 
to thus isolate the former demographic characteristics. The first panel of Table 6 shows these predictions across the three levels of food insecurity. First, among this demographic group, the presence of grandchildren has a startling effect on the probability of food insecurity. Even though this group of young seniors who are college educated should be low risk, adding a grandchild to the household raises the predicted probability of marginal food insecurity and food insecurity by at least a factor of 2, and of very low food security by a factor of 3 . While income is a key protective factor against food insecurity for these households without or with grandchildren present, the model still predicts that this hypothetical family with a grandchild living in the home and family income above twice the poverty line is at comparable risk of food insecurity than a similar family with no grandchild in the household but whose income is between one and two times the poverty line.

In the bottom panel of Table 6 we repeat the exercise but for a much higher food insecurity risk group. Here we focus on a female African American who is divorced or separated, disabled, between the ages of 45-49, a high school graduate, and living in a metro area. The bottom panel makes clear that food insecurity risk is extremely high for this demographic group — at least four times higher than in the top panel for those without grandchildren living in the household and with incomes below the poverty line, and ten times higher than those with incomes over twice the poverty line. Indeed, even though income remains protective for this group, the high levels even above twice the poverty line underscore the complexity of food insecurity as other factors such as race, disability, education, and family structure all play significant roles beyond income. This complexity is manifest in the bottom panel after we add grandchildren to the mix in that rates of very low food security, and to a lesser extent food insecurity, actually fall with the addition of grandchildren to the household. This 
could occur if, for example, the grandchild brings resources into the household such as additional food assistance benefits that serve as a buffer for these disadvantaged families from experiencing even more severe forms of food insecurity. We return to this issue in the next section on food insecurity transitions.

\section{Family Structure and the Determinants of Food Insecurity Transitions}

We extend the prior static analysis to examine more formally possible links between family structure dynamics and food security dynamics. Moreover, we examine whether other socioeconomic changes, such as falling into poverty, affect the risk of entry into food insecurity, as well as the effect of macroeconomic changes in labor market performance on food security.

The baseline transition regression model is:

$$
\Delta F I_{i t}=Z_{i 1} \beta+\Delta \mathrm{Z}_{\mathrm{it}} \theta+\eta_{1} G C_{i t}^{1}+\eta_{2} G C_{i t}^{2}+\eta_{3} G C_{i t}^{3}+u_{i t}
$$

where $\Delta F I$ refers to the entry into or exit from food security, $Z_{i 1}$ refers to year 1 demographics and state-level macroeconomic conditions, $\Delta Z_{i t}$ refers to changes in demographics (for those that can change, but excluding grandchildren variables) and state macro conditions between years 1 and 2, $G C_{i t}^{1}$ equals 1 if a grandchild moves in from period 1 to $2, G C_{i t}^{2}$ equals 1 if a grandchild moves out from period 1 to 2, and $G C_{i t}^{3}$ equals 1 if a grandchild is present in both periods. As the sample for the regression model contains families with and without grandchildren present, this means the reference (omitted) group is those households with no grandchild present in either period. We assume that after controlling for year fixed effects the error term, $u_{i t}$, is uncorrelated with the variables on the right hand side of equation (2) and thus we estimate the models with ordinary least squares.

The analysis here differs from the static model in equation (1) in two key ways. First, because we are estimating changes in food security status rather than levels, and some of the 
transition cells in Table 2 are somewhat sparsely populated, we specify a pooled model in (2) where the unknown coefficients $\beta$ and $\theta$ are assumed to be the same across families with and without resident grandchildren. Thus grandchildren only have an intercept shift on transition probabilities via the $\eta_{j}, j=1,2,3$, and do not affect the whole vector of demographics as in Tables 3-5. Second, and again related to potential concerns on small transition cell sizes, we use a more parsimonious set of demographic control variables. For example, instead of distinguishing four different categories of income, we identify whether the person's income falls below the Federal poverty line in year 1, but then also control for whether they exit poverty in year 2 or enter poverty in year 2. Moreover, we examine the effects of entry into and exit out of marriage and employment. We also introduce controls for levels and changes in state macroeconomic conditions on transitions probabilities via that state unemployment rate and state employment per capita.

We begin in Table 7 with entry and exit models utilizing the non-mutually exclusive categories of marginally food insecure and food insecure; that is, the entry models define the dependent variable as 1 for an individual who is fully food secure in year 1 and either marginally food insecure (column 1) or food insecure (column 2) in year 2. The exit models define the dependent variable as 1 if the person is marginally food insecure in year 1 (column 3) and fully food secure in year 2, or food insecure in year 1 (column 4) and fully food secure in year 2.

The results in Table 7 indicate that poverty status in year 1 is a strong predictor of entry into food insecurity, and a barrier to exit. An adult in poverty is 15.9 percentage points more likely to enter marginal food insecurity and 9.8 percentage points more likely to enter food insecurity than an adult not in poverty. Likewise, being in poverty results in nearly a 20 percentage point reduction in the probability of exit into full food security. Controlling for 
poverty status and other risk factors, African Americans and Hispanics are much more likely to enter MFI or FI than similarly situated white persons. But interestingly, they are no more or less likely to exit marginal food insecurity to full food security, and are actually more likely to exit food insecurity to full food security (by 2.6 and 5.1 percentage points, respectively). This suggests that there is more churning of food insecurity status among non-whites than whites.

Table 7 shows that age is protective of entry into food insecurity, and hastens exit, albeit both effects are small in magnitude. On the other hand, higher education is substantively protective of entry - a college graduate is 7.7 and 3.8 percentage points less likely to enter MFI or FI, respectively, than a high school dropout—suggesting that formal human capital attainment has positive benefits in preventing food insecurity over and above the increased incomes associated with more education. Marriage protects against entry and fosters exit from MFI relative to being never married, but never married adults are much less likely than divorced or separated adults to enter food insecurity and more likely to exit, which suggests that instability in family structure spills over into instability in food security. Likewise, compared to employed adults, retirees, the unemployed, and the disabled are more likely to enter, and less likely to exit, either marginal food insecurity or food insecurity. The quantitative magnitudes for the unemployed and disabled are quite large suggesting they are particularly at risk of entering and remaining in food insecurity. On the other hand, as the only proxy for wealth available in the December CPS, home owners are much less likely to enter and more likely to exit MFI or FI. This is perhaps due to the fact that these households can borrow against the equity in their homes to avoid a spell of food insecurity. As is often the case in models like this, controlling for personal characteristics, state economic conditions do not have a consistent effect on food insecurity. 
The last set of variables in Table 7 focus on demographic and economic "shocks" to the household. The focal family structure variables of interest are the three capturing presence of grandchildren. Relative to a family with no grandchild present in either year, if a grandchild enters the household between years 1 and 2, the family is 5.8 percentage points more likely to enter MFI and 4 percentage points more likely to enter FI. Likewise, they are 9.7 and 6.9 percentage points less likely to exit MFI or FI, respectively. If the grandchild exits between periods one and two, there is little evidence of change in food security status (except for some evidence of increased risk to enter FI, and reduced risk to exit MFI). If the grandchild is present in both years the family remains at elevated risk of entering either form of food insecurity, and they are less likely to exit MFI. Combined the estimates suggest that whether grandchildren remain, or in periods of transition, multigenerational families are at heightened risk of entering food insecurity and remaining in this state.

Changes in marital status also have a substantive impact on food insecurity transitions, and these magnitudes are especially large in the exit models. Likewise, employment shocks into and out of employment, and income shocks of falling into or exiting from poverty, have large impacts on the risk of entering and exiting food insecurity. Finding a job or exiting poverty both reduce the chances of entering food insecurity, and increase the odds of exiting food insecurity. The opposite occurs when the adult loses a job or enters employment. Again, we find that once we control for person-specific socioeconomic changes in income and employment status, statelevel portrayals of macroeconomic shocks in employment and unemployment do not influence the odds of entering or exiting food insecurity.

In Table 8 we unpack the non-mutually exclusive categories of MFI and FI to examine heterogeneity of transitions across mutually exclusive categories. In this case we examine 
sequential models of entry from FFS to MFS, from MFS to LFS, and from LFS to VLFS. Likewise, we estimate sequential models of exit from MFS to FFS, LFS to MFS, and VLFS to LFS. Because each of these transitions become increasingly less common, the sample sizes necessarily get smaller and thus reduce efficiency of the point estimates relative to the pooled models in Table 7.

The estimates in Table 8 show that most of the poverty-inducing effect of entry into food insecurity in Table 7 comes from movements from FFS to MFS or MFS to LFS and not from changes from LFS to VLFS. However, the “absorbing” effect of poverty status on reduced exits from food insecurity appears to be strong across all three exit models in columns (4) to (6). The race and ethnicity variables suggest that the bulk of the risk for food insecurity among African Americans and Hispanics is in moving into MFS. Interestingly, Hispanics are less likely to transition into LFS from MFS compared to whites, and are more likely to exit VLFS to LFS, suggesting again that there is substantial churning across food security states among Hispanic adults. Age is protective against food insecurity entry, except at the extreme level of VLFS, but older Americans are more likely to exit any given state of food insecurity to a greater level of food security. Higher education has a similar effect on entry, but no consistent statistically significant effect across food insecurity exits. Among the marital status and employment related variables, disability has the overwhelmingly largest effect across the individual categories in terms of moving into higher levels of food insecurity, and staying there.

The entry of a grandchild into the household appears to have the largest effect of moving families from full food secure to marginal, and from marginal to low, and to inhibit exit from marginal food security to full food security. However, when a grandchild does enter, a family is more likely to exit the most extreme form of insecurity to a less extreme form. As noted above 
in the discussion of the risk profiles in Table 6, this could occur, for example, if the child's entry into the household includes new financial resources such as higher food assistance benefits or kinship foster care payments. This possibility of resource change is furthered in the next row where we see that the exit of a grandchild increases the odds of entering VLFS from LFS by 13.8 percentage points. In terms of the other socioeconomic shocks, exiting employment or entering poverty each have fairly consistent effects of enhancing entry into worsening food security states and of staying in those worse states.

\section{Discussion}

Using data from the 2001-2010 Core Food Security Module in the Current Population Survey we find that rates of food insecurity in households with a grandchild present are at least twice as high as households without a grandchild present and very low food security increased substantially faster among these households over the past decade. In our multivariate regression analyses we find some important distinctions between families with and without resident grandchildren. First, the evidence of a declining age gradient among multigenerational families is weak compared to those with no grandchildren present. This suggests that the presence of grandchildren exacerbates anxiety about having sufficient resources to eat regardless of age. Second, the "food security disadvantage" of certain demographic characteristics is less pronounced when a grandchild is present. For example, being an African American increases the probability of marginal food insecurity by over 40 percent from the baseline mean of 14.9 percent for households with no grandchildren present, but this effect is just 16 percent when grandchildren are present. Third, the "food security advantage" of certain economic factors is more prevalent among households with grandchildren, most notable of these is the strong protective effect of having incomes above the poverty line and especially over twice the line. 
Our estimates from the longitudinally linked CPS data showed that the rise in food insecurity among adults age 40 and above after the onset of the Great Recession has occurred both because of increased entry into food insecurity and reduced exit. The rise in multigenerational families in the U.S. during the same recessionary period also came from increased entry and reduced exit of grandchildren into households, each relative to prerecessionary levels. In our multivariate regression analyses of transitions into and out of food insecurity we find that multigenerational families are at heighted risk of entering food insecurity and remaining in this state. We also find that employment and income shocks have strong effects on entry and exit of food insecurity, as well as disability status.

The transition models suggest a substantial amount of churning in food security states across periods. Our estimates especially point to the important role of family structure change on food security. In general we find that the presence of a grandchild is destabilizing and exposes the adult householder to greater food security risk. However, the entry of a grandchild may not always be a negative for the household's food security, nor the exit of the child a positive. Entrance of the child seems to buffer the family from extreme forms of food insecurity, perhaps owing to the fact that additional resources, whether transfers from the social safety net or from other relatives, likely flow into the family when the child arrives, and flow out when the child departs. There is a parallel to this result in DeLeire and Kalil (2002), who find that teenagers in single-mother families are less likely to engage in risky behaviors such as drinking and sexual activity after the entrance of a grandparent. They argue that the grandparent provides extra resources (time and money) that protects teenage children from worse outcomes. Although our study is from the perspective of the adult householder and the entrance and exit of the child is the source of protection from more extreme forms of food insecurity, both studies find that 
multigenerational families seem to reduce the odds of particularly high risk outcomes. However, on average, multigenerational families are more likely to be poor and to be food insecure, and thus policies that enhance the economic status of these families are likely to reduce food insecurity. For example, a just released report from the Annie E. Casey Foundation documents that less than 12 percent of kinship families receive assistance from TANF even though they are eligible, suggesting that enhanced outreach from this program may have the additional benefit of buffering multigenerational families from food insecurity. ${ }^{8}$ Moreover, given the evidence of the Supplemental Nutrition Assistance Program in alleviating food insecurity (e.g. Mykerezi and Mills, 2010; Ratcliffe et al., 2011; and Kreider et al., forthcoming), outreach efforts that increase participation in this program may be especially beneficial.

8

http://www.aecf.org/ /media/Pubs/Initiatives/KIDS\%20COUNT/S/SteppingUpforKids2012PolicyReport/SteppingU pForKidsPolicyReport2012.pdf 


\section{References}

Bollinger, C. and B. Hirsch. Forthcoming. “Is Earnings Nonresponse Ignorable?” Review of Economics and Statistics.

Cancian, M. and D. Reed. 2009. "Changes in Family Structure, Childbearing, and Employment: Implications for the Level and Trend in Poverty." In Maria Cancian and Sheldon Danziger, Eds, Changing Poverty. New York: Russell Sage Foundation.

Carmichael, S., W. Yang, A. Herring, B. Abrams, and G. Shaw. 2007. "Maternal Food Insecurity is Associated with Increased Risk of Certain Birth Defects." Journal of Nutrition, 137: 2087-2092.

Coleman-Jensen, A., M. Nord, M. Andrews, and S. Carlson. 2011. Household Food Security in the United States in 2010. USDA, Economic Research Report No. (ERR-125). 2011.

Cook, J., D. Frank, S. Levenson, N. Neault, T. Heeren, M. Black et al. 2006. "Child Food Insecurity Increases Risks Posed by Household Food Insecurity to Young Children’s Health.” Journal of Nutrition 136: 1073-1076.

DeLeire, T., and A. Kalil. 2002. "Good Things Come in Threes: Single-Parent Multigenerational Family Structure and Adolescent Adjustment.” Demography 39(2): 393-413.

Eicher-Miller H., A. Mason, C. Weaver, G. McCabe, and C. Boushey. 2009. "Food Insecurity is Associated with Iron Deficiency Anemia in U.S. Adolescents.” American Journal of Clinical Nutrition, 90: 1358-1371.

Gundersen, C., B. Kreider, and J. Pepper. 2011. "The Economics of Food Insecurity in the United States.” Applied Economic Perspectives and Policy, 33(3): 281-303.

Heflin, C., K. Siefert, and D. Williams. 2005. "Food Insufficiency and Women’s Mental Health: Findings from a 3-Year Panel of Welfare Recipients.” Social Science \& Medicine 61(9): 19711982.

Howard, L. 2011. "Does Food Insecurity at Home Affect Non-Cognitive Performance at School? A Longitudinal Analysis of Elementary Student Classroom Behavior.” Economics of Education Review 30: 157-176.

Huang, J., K. Matta Oshima, and Y. Kim. 2010. “Does Food Insecurity affect Parental Characteristics and Child Behavior? Testing Mediation Effects. Social Service Review, 84: 381401.

Kirkpatrick, S., L. McIntyre, and M. Potestio. 2010. "Child Hunger and Long-Term Adverse Consequences for Health.” Archives of Pediatric and Adolescent Medicine, 164 (8): 754-762. 
Kirkpatrick, S. and V. Tarasuk. 2007. Food Insecurity is Associated with Nutrient Intakes among Canadian Adults and Adolescents. Journal of Nutrition 138: 604-612.

Kreider, B, J Pepper, C Gundersen, and D Jolliffe. 2012. “Identifying the Effects of SNAP (Food Stamps) on Child Health Outcomes When Participation is Endogenous and Misreported." Journal of the American Statistical Association, 107 (499): 958-975.

Lee, J and E. Frongillo. 2001. "Nutritional and Health Consequences are Associated with Food Insecurity among Elderly Persons.” Journal of Nutrition, 131: 1503-1509.

McIntyre, L., and T. Glanville, K. Raine, J. Dayle, B. Anderson, and N. Battaglia N. 2003. "Do Low-Income Lone Mothers Compromise their Nutrition to Feed their Children?” Canadian Medical Association Journal 198: 686-691.

Muirhead, V., C. Quiñonez, R. Figueiredo, and D. Locker. 2009. “Oral Health Disparities and Food Insecurity in Working Poor Canadians.” Coummunity and Dental Oral Health, 37: 294304.

Mykerezi, E and B. Mills. 2010. “The Impact of Food Stamp Program Participation on Household Food Insecurity.” American Journal of Agricultural Economics 92 (5): 1379-1391.

Ratcliffe, C, S McKernan, and S Zhang. 2011. "How Much Does the Supplemental Nutrition Assistance Program Reduce Food Insecurity?” American Journal of Agricultural Economics 93(4): 1082-1098.

Seligman, H., A. Bindman, E. Vittinghoff, A. Kanaya, and M. Kushel. 2007. "Food Insecurity is Associated with Diabetes Mellitus: Results from the National Health Examination and Nutritional Examination Survey 1999-2002.” Journal of General and Internal Medicine, 22: 1018-1023.

Seligman, H., B. Laraia, and M. Kushel. 2009. "Food Insecurity Is Associated with Chronic Disease among Low-Income NHANES Participants.” Journal of Nutrition 140: 304-310.

Siefert, K., C. Heflin, M. Corcoran, and D. Williams. 2004. “Food Insufficiency and Women’s Health: Findings from a Longitudinal Study of Welfare Recipients.” Journal of Health and Social Behavior 45(2):171-186.

Skalicky, A., W. Meyers, Z. Adams, Z. Yang, J. Cook, and D. Frank. 2006. “Child Food Insecurity and Iron Deficiency Anemia in Low-Income Infants and Toddlers in the United States.” Maternal and Child Health Journal, 10(2): 177-185.

Stuff, J., P. Casey, K. Szeto, J. Gossett, J. Robbins, P. Simpson, et al. 2004. "Household Food Insecurity is Associated with Adult Health Status. Journal of Nutrition, 134: 2330-2335.

Tarasuk, V. 2001. “Household Food Insecurity with Hunger is Associated with Woman’s Food Intakes, Health and Household Circumstances.” Journal of Nutrition, 131: 2670-2676. 
Taylor, P., J. Passel, R. Fry, R. Morin, W. Wang, G. Velasco, and D. Dockterman. 2010. “The Return of the Multi-Generational Household,” Pew Research Center, http://pewsocialtrends.org/files/2010/10/752-multi-generational-families.pdf

Whitaker, R., S. Phillips, and S. Orzol. 2006. "Food Insecurity and the Risks of Depression and Anxiety in Mothers and Behavior Problems in their Preschool-Aged Children.” Pediatrics, 118: e859-e868.

Wooldridge, J. 2002. Econometric Analysis of Cross Section and Panel Data. Cambridge, MA: MIT Press.

Ziliak, J. and C. Gundersen. 2012. Senior Hunger in America 2010: An Annual Report. Report submitted to the Meals On Wheels Research Foundation.

Ziliak, J., C. Gundersen, and M. Haist. 2008. The Causes, Consequences, and Future of Senior Hunger in America. Technical Report submitted to the Meals on Wheels Association of America Foundation. 
Figure 1. Percent of Householders Age 40+ with Grandchildren Present by Race

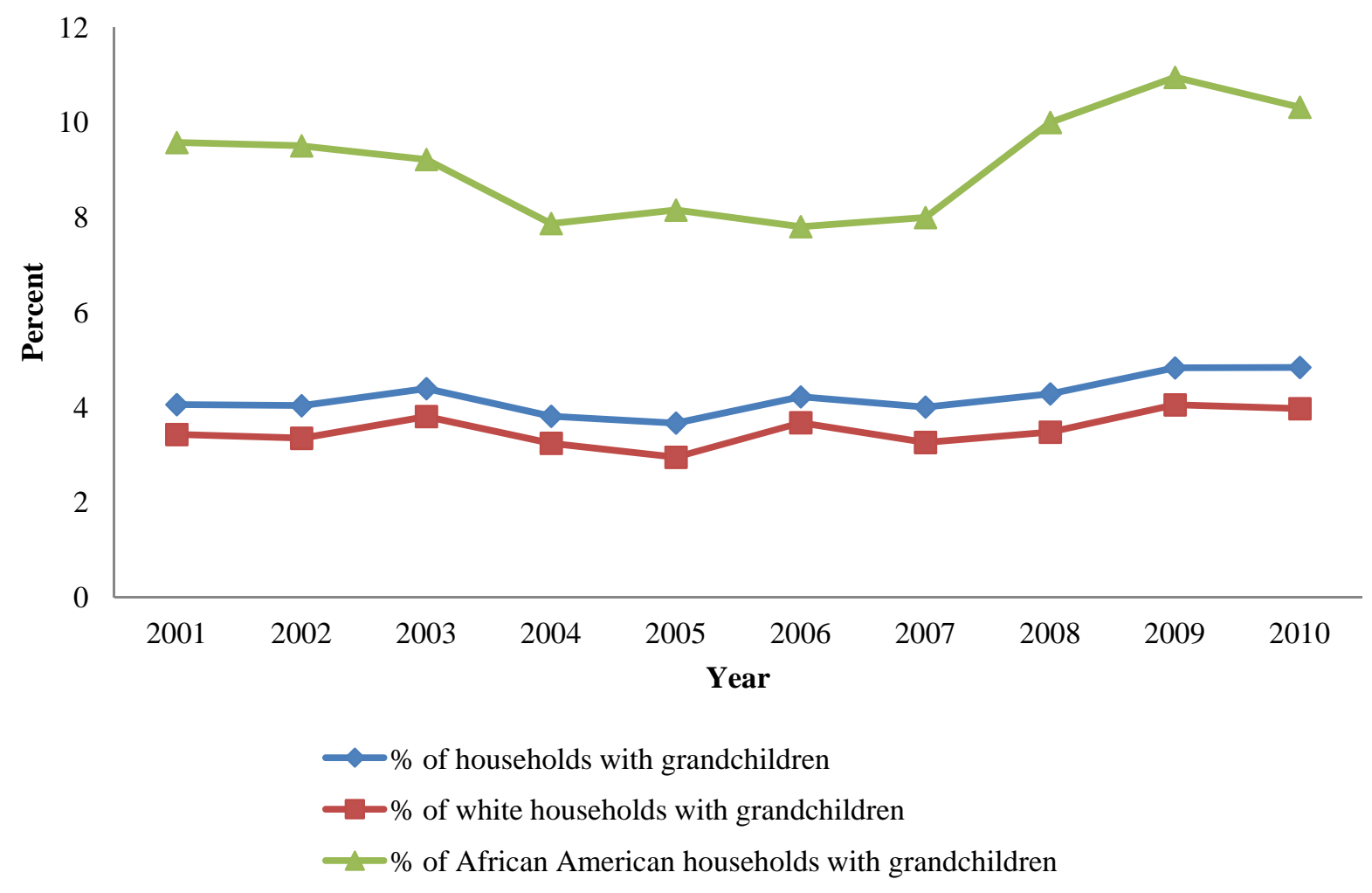


Figure 2. Percentage of Householders Age 40+ with Grandchildren Present by Poverty Status

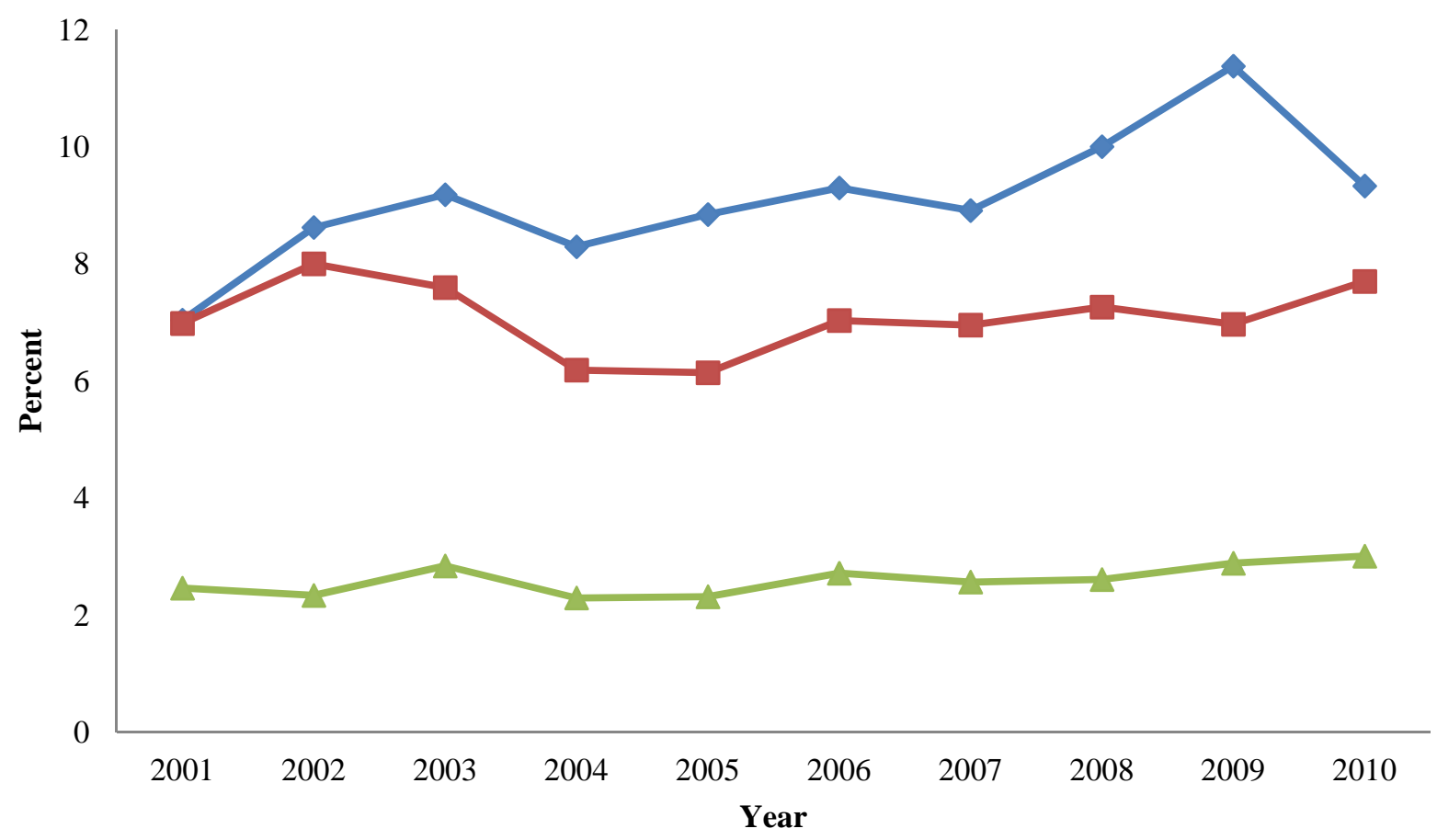

- Income $<=100 \%$ FPL $-100 \%$ FPL $<$ Income $<=200 \%$ FPL $\longrightarrow$ Income $>200 \%$ FPL 
Figure 3. Food Insecurity among Adults Age 40+

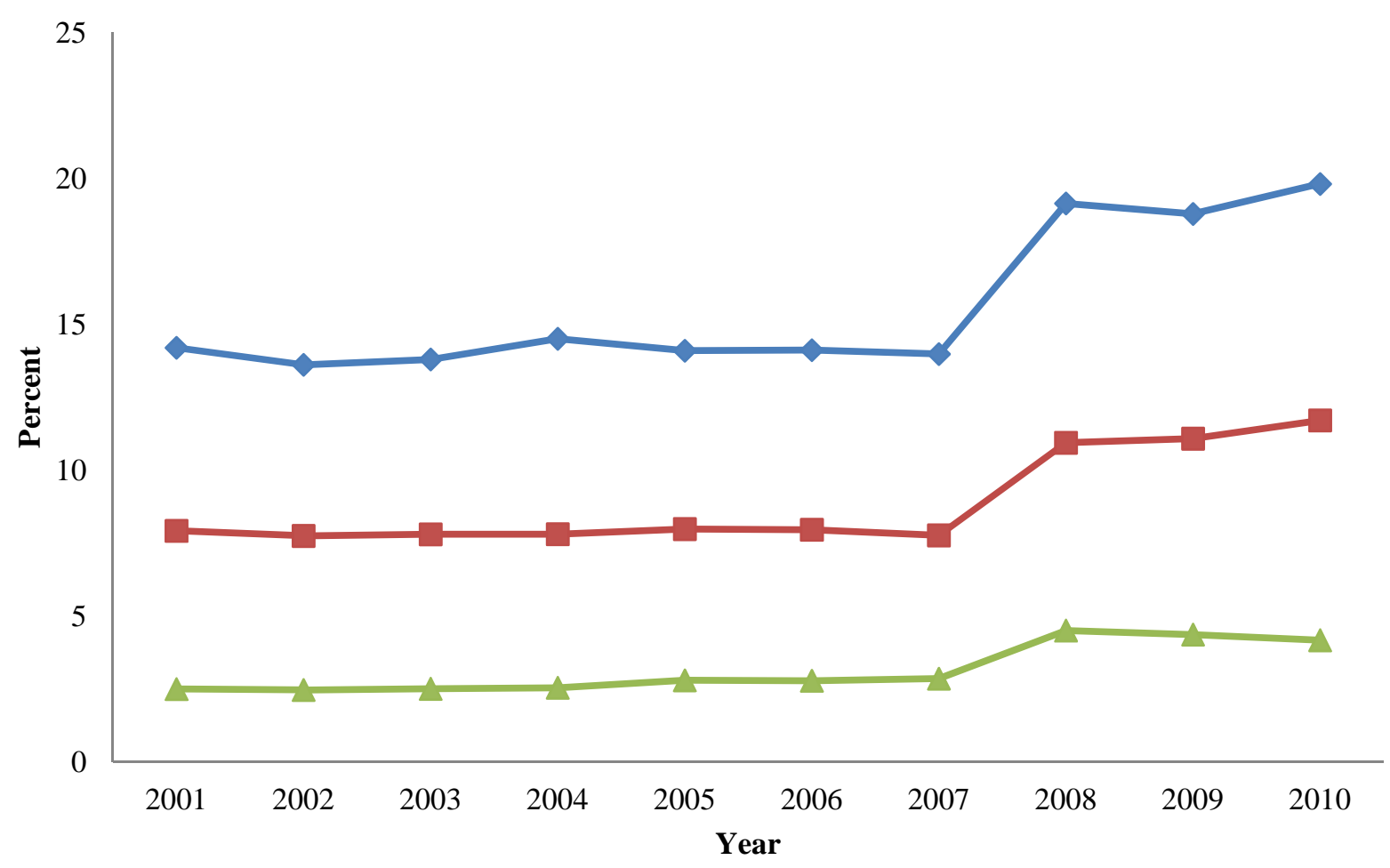

$\neg$ marginally food insecure $\quad \rightarrow$ food insecure $\rightarrow$ very low food secure 
Figure 4. Food Insecurity among Householders Age 40+ with and without Grandchildren Present

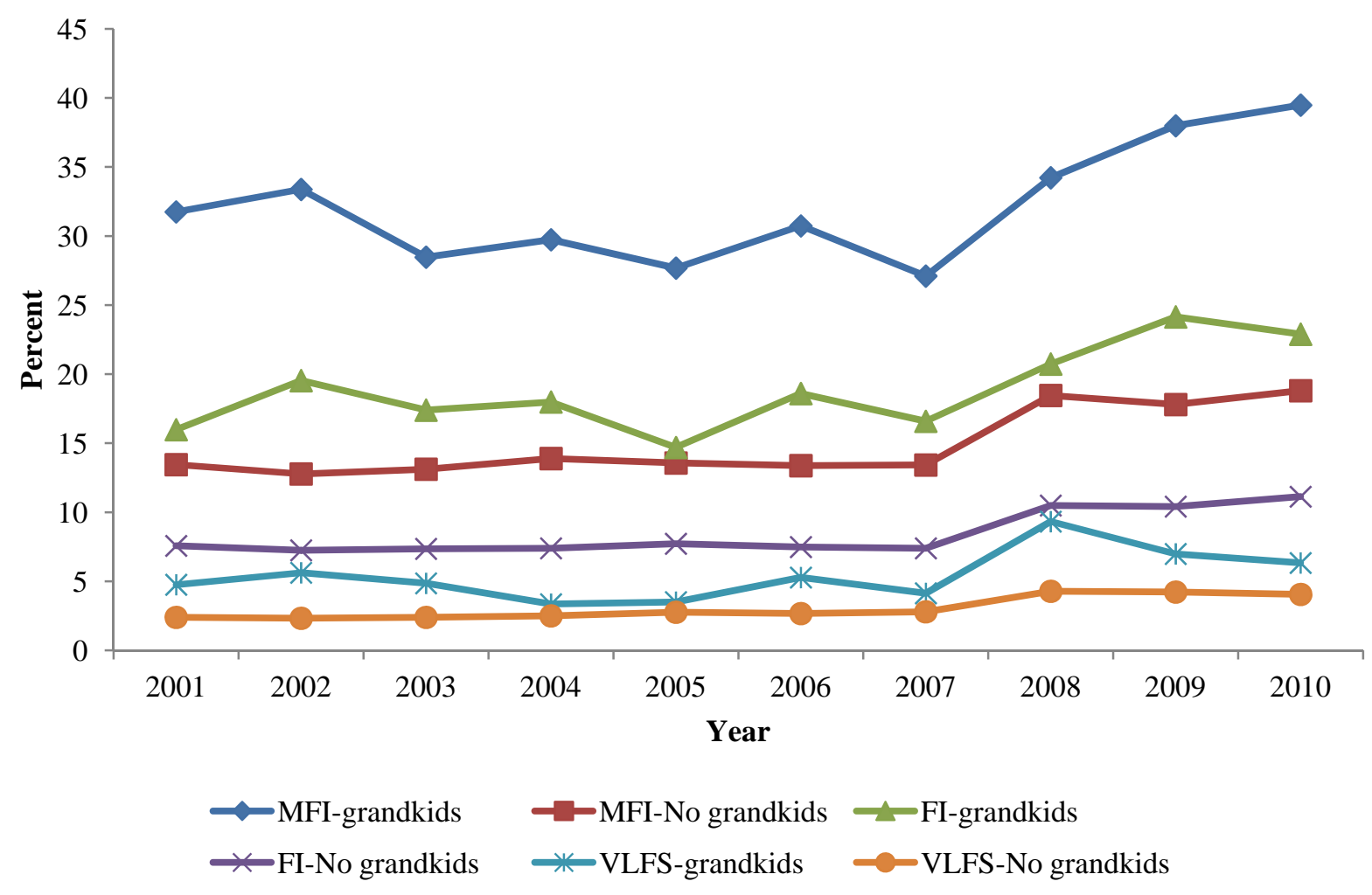


Figure 5. Entry and Exit Rates into Marginal Food Insecurity

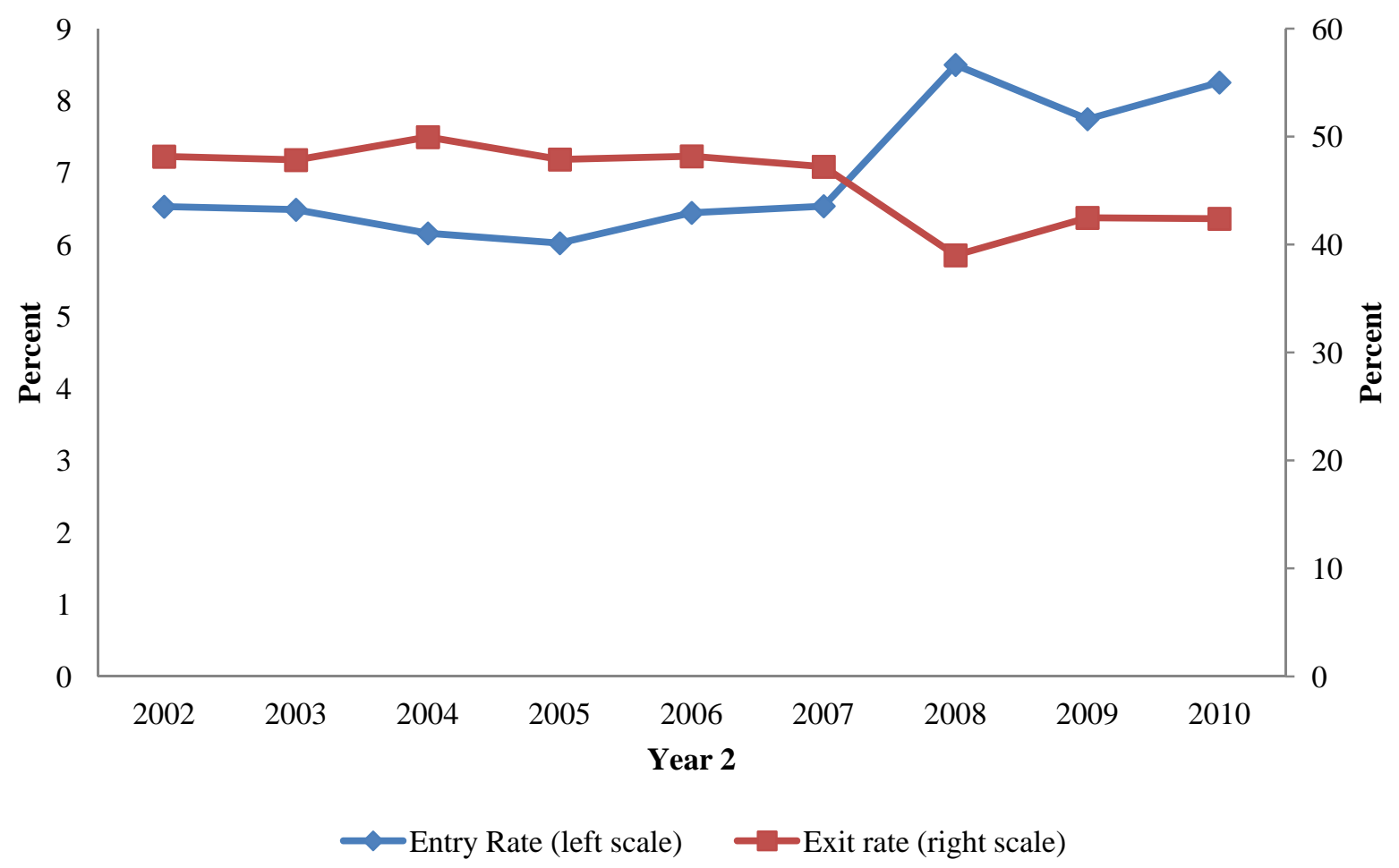


Figure 6. Entry and Exit Rates of Grandchildren

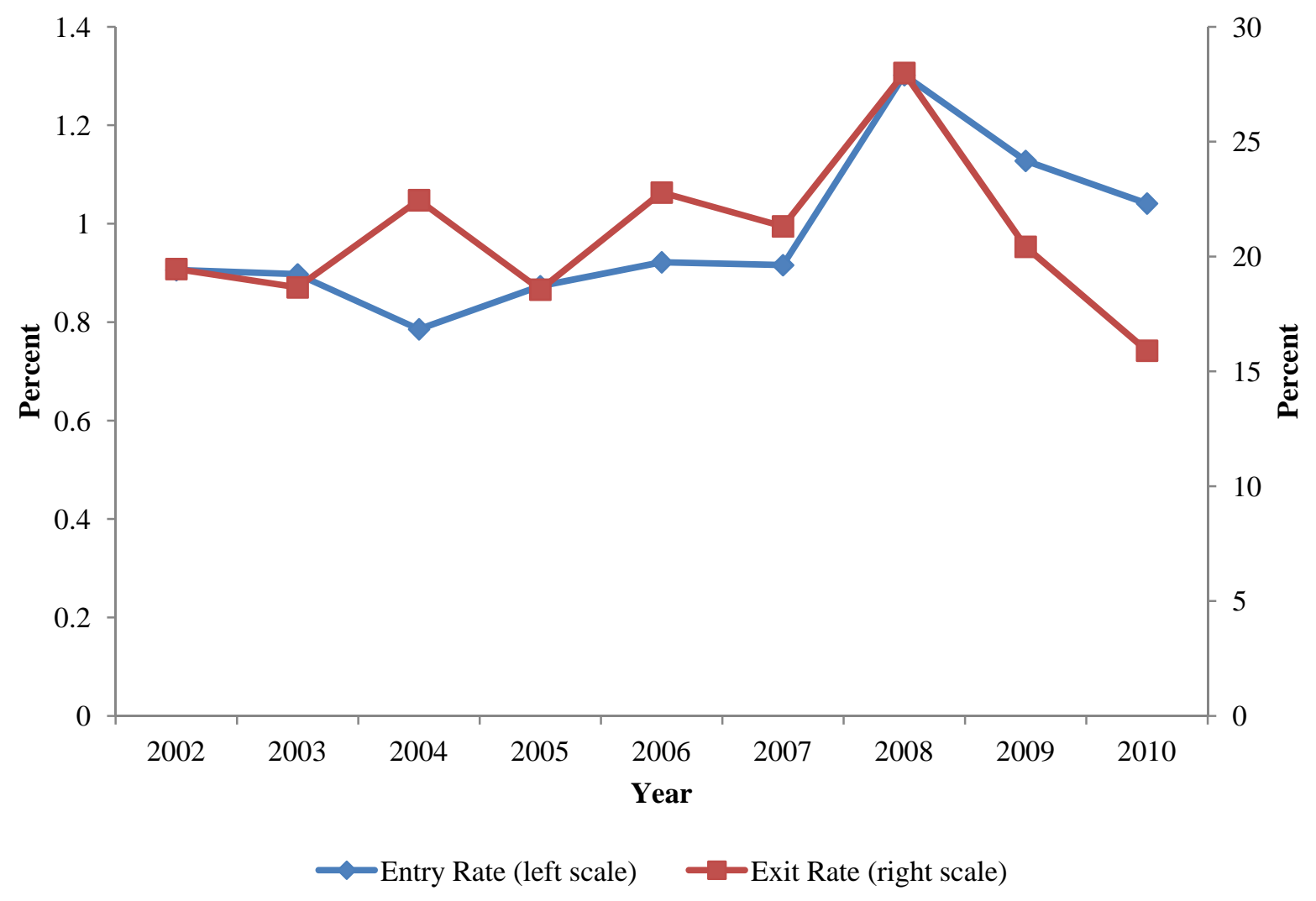


Table 1. Selected Characteristics of Adults Age 40+ in the Current Population Survey, 2001-2010

\begin{tabular}{|c|c|c|c|}
\hline & All & $\begin{array}{c}\text { No Grandchildren } \\
\text { Present } \\
\end{array}$ & $\begin{array}{c}\text { Grandchildren } \\
\text { Present } \\
\end{array}$ \\
\hline \multicolumn{4}{|l|}{ Income Categories } \\
\hline Below 50\% of the Poverty Line & 2.30 & 2.15 & $5.57 *$ \\
\hline Between $50 \%$ and $100 \%$ of the Poverty Line & 5.92 & 5.64 & $12.17^{*}$ \\
\hline Between $100 \%$ and $200 \%$ of the Poverty Line & 14.22 & 13.79 & $23.96 *$ \\
\hline Above $200 \%$ of the Poverty Line & 56.61 & 57.56 & $35.00 *$ \\
\hline Missing Income & 20.95 & 20.84 & $23.31 *$ \\
\hline \multicolumn{4}{|l|}{ Racial Categories } \\
\hline White & 83.81 & 84.42 & 69.96* \\
\hline African American & 10.76 & 10.20 & $23.33^{*}$ \\
\hline Other & 5.43 & 5.38 & $6.71^{*}$ \\
\hline Hispanic Ethnicity & 9.24 & 8.83 & $18.59 *$ \\
\hline \multicolumn{4}{|l|}{ Marital Status } \\
\hline Married & 65.42 & 65.70 & $59.13^{*}$ \\
\hline Widowed & 10.45 & 10.30 & $13.79 *$ \\
\hline Divorced or Separated & 15.38 & 15.21 & $19.26^{*}$ \\
\hline Never Married & 8.74 & 8.78 & $7.83^{*}$ \\
\hline Homeowner & 81.48 & 81.58 & $79.21^{*}$ \\
\hline \multicolumn{4}{|l|}{ Geographic Location } \\
\hline Non-Metro & 18.76 & 18.74 & 19.08 \\
\hline Northeast & 19.39 & 19.56 & $15.58^{*}$ \\
\hline Midwest & 22.64 & 22.87 & $17.38^{*}$ \\
\hline South & 36.10 & 35.74 & $44.24^{*}$ \\
\hline West & 21.88 & 21.83 & $22.80^{*}$ \\
\hline \multicolumn{4}{|l|}{ Age } \\
\hline 40 to 44 & 16.65 & 16.82 & $12.74^{*}$ \\
\hline 45 to 49 & 16.83 & 16.86 & 16.25 \\
\hline 50 to 54 & 15.40 & 15.38 & 15.89 \\
\hline 55 to 59 & 13.17 & 13.06 & $15.64^{*}$ \\
\hline 60 to 64 & 10.51 & 10.38 & $13.42^{*}$ \\
\hline 65 to 69 & 8.09 & 8.01 & $9.75^{*}$ \\
\hline 70 to 74 & 6.53 & 6.52 & 6.76 \\
\hline 75 to 79 & 5.68 & 5.72 & $4.92 *$ \\
\hline 80 and older & 7.14 & 7.26 & $4.63^{*}$ \\
\hline \multicolumn{4}{|l|}{ Employment Status } \\
\hline Employed & 57.05 & 57.37 & $49.81^{*}$ \\
\hline Unemployed & 2.87 & 2.84 & $3.50 *$ \\
\hline Retired & 26.97 & 27.07 & $24.69 *$ \\
\hline Disabled & 13.09 & 12.70 & $21.99 *$ \\
\hline \multicolumn{4}{|l|}{ Education Level } \\
\hline Less Than High School & 14.75 & 14.14 & $28.55^{*}$ \\
\hline
\end{tabular}




\begin{tabular}{lccc} 
High School Diploma & 32.33 & 32.10 & $37.65^{*}$ \\
$\quad$ Some College & 25.39 & 25.50 & $22.81^{*}$ \\
$\quad$ College Degree & 27.53 & 28.26 & $10.99^{*}$ \\
Food Stamp Recipient & 4.49 & 3.96 & $16.53^{*}$ \\
Grandchild or Parent Present & & & \\
$\quad$ No Grandchild or Parent & 95.78 & 100.00 & $0.00^{\mathrm{a}}$ \\
Grandchild and Parent & 3.10 & 0.00 & $73.34^{*}$ \\
$\quad$ Grandchild Only & 1.13 & 0.00 & $26.66^{*}$ \\
Female & 52.92 & 52.56 & $61.13^{*}$ \\
Living Alone & 17.99 & 18.79 & $0.00^{\mathrm{a}}$ \\
Marginal Food Insecure & 15.69 & 14.96 & $32.46^{*}$ \\
Food Insecure & 8.93 & 8.48 & $19.18^{*}$ \\
Very Low Food Secure & 3.18 & 3.07 & $5.55^{*}$ \\
\hline
\end{tabular}

* Denotes the difference in means between samples with and without grandchildren are statistically different from zero at the $5 \%$ level. There are 263,790 observations (10,338 with grandchild present; 253,452 without). ${ }^{\text {a }}$ Denotes no basis for comparison. 
Table 2. Two-Year Transition Probabilities in Food Security Status

\begin{tabular}{|c|c|c|c|c|}
\hline & \multicolumn{4}{|c|}{ Year 2 food security status conditional on y1 status } \\
\hline \multicolumn{5}{|c|}{ Full Sample } \\
\hline Year 1 status & FFS & MFS & LFS & VLFS \\
\hline FFS & 0.93 & 0.04 & 0.02 & 0.01 \\
\hline MFS & 0.60 & 0.22 & 0.14 & 0.04 \\
\hline LFS & 0.40 & 0.21 & 0.28 & 0.12 \\
\hline VLFS & 0.24 & 0.12 & 0.24 & 0.40 \\
\hline \multicolumn{5}{|c|}{ No Grandchildren } \\
\hline & FFS & MFS & LFS & VLFS \\
\hline FFS & 0.93 & 0.04 & 0.02 & 0.01 \\
\hline MFS & 0.60 & 0.22 & 0.13 & 0.04 \\
\hline LFS & 0.40 & 0.21 & 0.27 & 0.12 \\
\hline VLFS & 0.24 & 0.12 & 0.23 & 0.41 \\
\hline \multicolumn{5}{|c|}{ Grandchildren both years } \\
\hline & FFS & MFS & LFS & VLFS \\
\hline FFS & 0.84 & 0.10 & 0.06 & 0.01 \\
\hline MFS & 0.55 & 0.22 & 0.19 & 0.04 \\
\hline LFS & 0.35 & 0.19 & 0.34 & 0.11 \\
\hline VLFS & 0.23 & 0.18 & 0.28 & 0.31 \\
\hline \multicolumn{5}{|c|}{ Grandchildren y1 only } \\
\hline & FFS & MFS & LFS & VLFS \\
\hline FFS & 0.87 & 0.06 & 0.04 & 0.03 \\
\hline MFS & 0.51 & 0.20 & 0.18 & 0.11 \\
\hline LFS & 0.44 & 0.23 & 0.20 & 0.13 \\
\hline VLFS & 0.10 & 0.08 & 0.29 & 0.52 \\
\hline \multicolumn{5}{|c|}{ Grandchildren y2 only } \\
\hline & FFS & MFS & LFS & VLFS \\
\hline FFS & 0.85 & 0.07 & 0.06 & 0.02 \\
\hline MFS & 0.45 & 0.27 & 0.24 & 0.04 \\
\hline LFS & 0.30 & 0.26 & 0.34 & 0.11 \\
\hline VLFS & 0.21 & 0.07 & 0.41 & 0.32 \\
\hline
\end{tabular}

Note: Data from 163,777 longitudinal matches of the 2001-2010 December Current Population Surveys. FFS=Fully Food Secure, MFS=Marginally Food Secure, LFS=Low Food Insecure, VLFS=Very Low Food Secure 
Table 3. Estimated Determinants of Marginal Food Insecurity Rates among Adults Age 40+ by Presence of Grandchildren

No Grandchildren With Grandchildren

\begin{tabular}{|c|c|c|c|c|}
\hline & Coefficients & Marginal Effects & Coefficients & Marginal Effects \\
\hline Constant & $\begin{array}{c}0.160 * * * \\
(0.032)\end{array}$ & & $\begin{array}{c}0.516^{* * *} \\
(0.123)\end{array}$ & \\
\hline African American & $\begin{array}{c}0.343^{* * *} \\
(0.013)\end{array}$ & $\begin{array}{c}0.062^{* * *} \\
(0.002)\end{array}$ & $\begin{array}{c}0.173^{* * *} \\
(0.042)\end{array}$ & $\begin{array}{c}0.051^{* * *} \\
(0.013)\end{array}$ \\
\hline Other Race & $\begin{array}{c}0.067 * * * \\
(0.019)\end{array}$ & $\begin{array}{c}0.012 * * * \\
(0.004)\end{array}$ & $\begin{array}{l}-0.013 \\
(0.069)\end{array}$ & $\begin{array}{l}-0.004 \\
(0.020)\end{array}$ \\
\hline Hispanic & $\begin{array}{c}0.217^{* * *} \\
(0.015)\end{array}$ & $\begin{array}{c}0.039 * * * \\
(0.003)\end{array}$ & $\begin{array}{c}0.124 * * \\
(0.049)\end{array}$ & $\begin{array}{c}0.037 * * \\
(0.015)\end{array}$ \\
\hline High School & $\begin{array}{c}-0.205^{* * *} \\
(0.012)\end{array}$ & $\begin{array}{c}-0.037 * * * \\
(0.002)\end{array}$ & $\begin{array}{c}-0.199 * * * \\
(0.042)\end{array}$ & $\begin{array}{c}-0.059 * * * \\
(0.012)\end{array}$ \\
\hline Some College & $\begin{array}{c}-0.250 * * * \\
(0.013)\end{array}$ & $\begin{array}{c}-0.046^{* * *} \\
(0.002)\end{array}$ & $\begin{array}{c}-0.238^{* * *} \\
(0.049)\end{array}$ & $\begin{array}{c}-0.070^{* * *} \\
(0.014)\end{array}$ \\
\hline College & $\begin{array}{c}-0.571^{* * *} \\
(0.015)\end{array}$ & $\begin{array}{c}-0.104^{* * *} \\
(0.003)\end{array}$ & $\begin{array}{c}-0.382 * * * \\
(0.066)\end{array}$ & $\begin{array}{c}-0.113^{* * *} \\
(0.020)\end{array}$ \\
\hline Married & $\begin{array}{c}-0.114^{* * *} \\
(0.016)\end{array}$ & $\begin{array}{c}-0.021^{* * *} \\
(0.003)\end{array}$ & $\begin{array}{l}-0.039 \\
(0.065)\end{array}$ & $\begin{array}{c}-0.012 \\
(0.019)\end{array}$ \\
\hline Widowed & $\begin{array}{c}0.124^{* * *} \\
(0.020)\end{array}$ & $\begin{array}{c}0.023^{* * *} \\
(0.004)\end{array}$ & $\begin{array}{c}0.179 * * \\
(0.078)\end{array}$ & $\begin{array}{c}0.053^{* *} \\
(0.023)\end{array}$ \\
\hline Divorced/Separated & $\begin{array}{c}0.194 * * * \\
(0.016)\end{array}$ & $\begin{array}{c}0.035 * * * \\
(0.003)\end{array}$ & $\begin{array}{c}0.214^{* * *} \\
(0.069)\end{array}$ & $\begin{array}{c}0.063^{* * *} \\
(0.021)\end{array}$ \\
\hline Age $44-49$ & $\begin{array}{c}-0.043^{* * *} \\
(0.013)\end{array}$ & $\begin{array}{c}-0.008^{* * *} \\
(0.002)\end{array}$ & $\begin{array}{l}0.116^{*} \\
(0.061)\end{array}$ & $\begin{array}{l}0.034^{*} \\
(0.018)\end{array}$ \\
\hline Age $50-54$ & $\begin{array}{c}-0.100 * * * \\
(0.014)\end{array}$ & $\begin{array}{c}-0.018^{* * *} \\
(0.003)\end{array}$ & $\begin{array}{c}0.067 \\
(0.061)\end{array}$ & $\begin{array}{c}0.020 \\
(0.018)\end{array}$ \\
\hline Age 55-59 & $\begin{array}{c}-0.202^{* * *} \\
(0.015)\end{array}$ & $\begin{array}{c}-0.037^{* * *} \\
(0.003)\end{array}$ & $\begin{array}{c}0.030 \\
(0.062)\end{array}$ & $\begin{array}{c}0.009 \\
(0.018)\end{array}$ \\
\hline Age 60-64 & $\begin{array}{c}-0.230 * * * \\
(0.017)\end{array}$ & $\begin{array}{c}-0.042^{* * *} \\
(0.003)\end{array}$ & $\begin{array}{l}-0.030 \\
(0.065)\end{array}$ & $\begin{array}{l}-0.009 \\
(0.019)\end{array}$ \\
\hline Age 65-69 & $\begin{array}{c}-0.331^{* * *} \\
(0.020)\end{array}$ & $\begin{array}{c}-0.060 * * * \\
(0.004)\end{array}$ & $\begin{array}{l}-0.125 \\
(0.077)\end{array}$ & $\begin{array}{l}-0.037 \\
(0.023)\end{array}$ \\
\hline Age $70-74$ & $\begin{array}{c}-0.346^{* * *} \\
(0.023)\end{array}$ & $\begin{array}{c}-0.063^{* * *} \\
(0.004)\end{array}$ & $\begin{array}{l}-0.147^{*} \\
(0.089)\end{array}$ & $\begin{array}{l}-0.044 * \\
(0.026)\end{array}$ \\
\hline Age 75-79 & $\begin{array}{c}-0.454^{* * *} \\
(0.025)\end{array}$ & $\begin{array}{c}-0.083^{* * *} \\
(0.004)\end{array}$ & $\begin{array}{l}-0.116 \\
(0.099)\end{array}$ & $\begin{array}{l}-0.034 \\
(0.029)\end{array}$ \\
\hline Age $80+$ & $\begin{array}{c}-0.597 * * * \\
(0.026)\end{array}$ & $\begin{array}{c}-0.109 * * * \\
(0.005)\end{array}$ & $\begin{array}{l}-0.134 \\
(0.104)\end{array}$ & $\begin{array}{l}-0.040 \\
(0.031)\end{array}$ \\
\hline 50-100\% Poverty & 0.039 & 0.007 & $-0.187 * *$ & $-0.055 * *$ \\
\hline
\end{tabular}




\begin{tabular}{|c|c|c|c|c|}
\hline & $(0.025)$ & $(0.005)$ & $(0.078)$ & $(0.023)$ \\
\hline 100-200\% Poverty & $\begin{array}{c}-0.195 * * * \\
(0.023)\end{array}$ & $\begin{array}{c}-0.035 * * * \\
(0.004)\end{array}$ & $\begin{array}{c}-0.510 * * * \\
(0.074)\end{array}$ & $\begin{array}{c}-0.151^{* * *} \\
(0.022)\end{array}$ \\
\hline > 200\% Poverty & $\begin{array}{c}-0.955 * * * \\
(0.023)\end{array}$ & $\begin{array}{c}-0.174 * * * \\
(0.004)\end{array}$ & $\begin{array}{c}-1.189 * * * \\
(0.077)\end{array}$ & $\begin{array}{c}-0.352 * * * \\
(0.022)\end{array}$ \\
\hline Missing Income & $\begin{array}{c}-0.886 * * * \\
(0.024)\end{array}$ & $\begin{array}{c}-0.161^{* * *} \\
(0.004)\end{array}$ & $\begin{array}{c}-0.979 * * * \\
(0.077)\end{array}$ & $\begin{array}{c}-0.290 * * * \\
(0.022)\end{array}$ \\
\hline Homeowner & $\begin{array}{c}-0.369 * * * \\
(0.010)\end{array}$ & $\begin{array}{c}-0.067 * * * \\
(0.002)\end{array}$ & $\begin{array}{c}-0.389 * * * \\
(0.041)\end{array}$ & $\begin{array}{c}-0.115^{* * *} \\
(0.012)\end{array}$ \\
\hline Non-Metro & $\begin{array}{c}0.015 \\
(0.010)\end{array}$ & $\begin{array}{c}0.003 \\
(0.002)\end{array}$ & $\begin{array}{l}-0.050 \\
(0.040)\end{array}$ & $\begin{array}{l}-0.015 \\
(0.012)\end{array}$ \\
\hline Retired & $\begin{array}{c}-0.092 * * * \\
(0.015)\end{array}$ & $\begin{array}{c}-0.017^{* * *} \\
(0.003)\end{array}$ & $\begin{array}{c}0.010 \\
(0.055)\end{array}$ & $\begin{array}{c}0.003 \\
(0.016)\end{array}$ \\
\hline Unemployed & $\begin{array}{c}0.516^{* * *} \\
(0.021)\end{array}$ & $\begin{array}{c}0.094^{* * *} \\
(0.004)\end{array}$ & $\begin{array}{c}0.346^{* * *} \\
(0.088)\end{array}$ & $\begin{array}{c}0.103^{* * *} \\
(0.026)\end{array}$ \\
\hline Disabled & $\begin{array}{c}0.314^{* * * *} \\
(0.012)\end{array}$ & $\begin{array}{c}0.057 * * * \\
(0.002)\end{array}$ & $\begin{array}{c}0.238 * * * \\
(0.042)\end{array}$ & $\begin{array}{c}0.071^{* * *} \\
(0.012)\end{array}$ \\
\hline Female & $\begin{array}{c}0.017 * * \\
(0.008)\end{array}$ & $\begin{array}{c}0.003 * * \\
(0.002)\end{array}$ & $\begin{array}{c}0.009 \\
(0.035)\end{array}$ & $\begin{array}{c}0.003 \\
(0.010)\end{array}$ \\
\hline South & $\begin{array}{c}0.004 \\
(0.011)\end{array}$ & $\begin{array}{c}0.001 \\
(0.002)\end{array}$ & $\begin{array}{c}0.103 * * \\
(0.045)\end{array}$ & $\begin{array}{c}0.031^{* *} \\
(0.013)\end{array}$ \\
\hline West & $\begin{array}{c}0.005 \\
(0.012)\end{array}$ & $\begin{array}{c}0.001 \\
(0.002)\end{array}$ & $\begin{array}{c}0.062 \\
(0.053)\end{array}$ & $\begin{array}{c}0.018 \\
(0.016)\end{array}$ \\
\hline Northeast & $\begin{array}{c}-0.040 * * * \\
(0.013)\end{array}$ & $\begin{array}{c}-0.007 * * * \\
(0.002)\end{array}$ & $\begin{array}{l}-0.035 \\
(0.057)\end{array}$ & $\begin{array}{l}-0.010 \\
(0.017)\end{array}$ \\
\hline Lives alone & $\begin{array}{c}-0.090^{* * *} \\
(0.013)\end{array}$ & $\begin{array}{c}-0.016 * * * \\
(0.002)\end{array}$ & & \\
\hline
\end{tabular}

$\begin{array}{lc}\text { Wald Test } & 180.480 \\ \text { dof, p-value } & {[31,0.00]}\end{array}$

Observations $\quad 252803 \quad 252803$

10299

10299

Robust standard errors in parentheses. ${ }^{* * *} \mathrm{p}<0.01$, ${ }^{* *} \mathrm{p}<0.05,{ }^{*} \mathrm{p}<0.1$ 
Table 4. Estimated Determinants of Food Insecurity Rates among Adults Age 40+ by Presence of Grandchildren

No Grandchildren With Grandchildren

\begin{tabular}{|c|c|c|c|c|}
\hline & Coefficients & Marginal Effects & Coefficients & Marginal Effects \\
\hline Constant & $\begin{array}{c}-0.275^{* * *} \\
(0.035)\end{array}$ & & $\begin{array}{l}-0.111 \\
(0.128)\end{array}$ & \\
\hline African American & $\begin{array}{c}0.287 * * * \\
(0.015)\end{array}$ & $\begin{array}{c}0.035^{* * *} \\
(0.002)\end{array}$ & $\begin{array}{c}0.222^{* * *} \\
(0.046)\end{array}$ & $\begin{array}{c}0.051^{* * *} \\
(0.011)\end{array}$ \\
\hline Other Race & $\begin{array}{c}0.087 * * * \\
(0.022)\end{array}$ & $\begin{array}{c}0.011^{* * *} \\
(0.003)\end{array}$ & $\begin{array}{c}0.085 \\
(0.073)\end{array}$ & $\begin{array}{c}0.020 \\
(0.017)\end{array}$ \\
\hline Hispanic & $\begin{array}{c}0.181^{* * *} \\
(0.017)\end{array}$ & $\begin{array}{c}0.022 * * * \\
(0.002)\end{array}$ & $\begin{array}{c}0.072 \\
(0.054)\end{array}$ & $\begin{array}{c}0.017 \\
(0.012)\end{array}$ \\
\hline High School & $\begin{array}{c}-0.193^{* * *} \\
(0.014)\end{array}$ & $\begin{array}{c}-0.024 * * * \\
(0.002)\end{array}$ & $\begin{array}{c}-0.176^{* * *} \\
(0.045)\end{array}$ & $\begin{array}{c}-0.041^{* * *} \\
(0.011)\end{array}$ \\
\hline Some College & $\begin{array}{c}-0.198 * * * \\
(0.016)\end{array}$ & $\begin{array}{c}-0.024 * * * \\
(0.002)\end{array}$ & $\begin{array}{c}-0.146^{* * *} \\
(0.054)\end{array}$ & $\begin{array}{c}-0.034^{* * *} \\
(0.012)\end{array}$ \\
\hline College & $\begin{array}{c}-0.519 * * * \\
(0.018)\end{array}$ & $\begin{array}{c}-0.064^{* * *} \\
(0.002)\end{array}$ & $\begin{array}{c}-0.295 * * * \\
(0.078)\end{array}$ & $\begin{array}{c}-0.068 * * * \\
(0.018)\end{array}$ \\
\hline Married & $\begin{array}{c}-0.101 * * * \\
(0.018)\end{array}$ & $\begin{array}{c}-0.012 * * * \\
(0.002)\end{array}$ & $\begin{array}{c}0.003 \\
(0.069)\end{array}$ & $\begin{array}{c}0.001 \\
(0.016)\end{array}$ \\
\hline Widowed & $\begin{array}{c}0.139 * * * \\
(0.024)\end{array}$ & $\begin{array}{c}0.017 * * * \\
(0.003)\end{array}$ & $\begin{array}{c}0.203^{* *} \\
(0.083)\end{array}$ & $\begin{array}{c}0.047^{* *} \\
(0.019)\end{array}$ \\
\hline Divorced/Separated & $\begin{array}{c}0.218 * * * \\
(0.018)\end{array}$ & $\begin{array}{c}0.027 * * * \\
(0.002)\end{array}$ & $\begin{array}{c}0.217 * * * \\
(0.072)\end{array}$ & $\begin{array}{c}0.050 * * * \\
(0.017)\end{array}$ \\
\hline Age 44-49 & $\begin{array}{l}-0.019 \\
(0.015)\end{array}$ & $\begin{array}{l}-0.002 \\
(0.002)\end{array}$ & $\begin{array}{c}0.041 \\
(0.065)\end{array}$ & $\begin{array}{c}0.009 \\
(0.015)\end{array}$ \\
\hline Age 50-54 & $\begin{array}{c}-0.092 * * * \\
(0.016)\end{array}$ & $\begin{array}{c}-0.011 * * * \\
(0.002)\end{array}$ & $\begin{array}{l}-0.034 \\
(0.066)\end{array}$ & $\begin{array}{l}-0.008 \\
(0.015)\end{array}$ \\
\hline Age 55-59 & $\begin{array}{c}-0.195^{* * *} \\
(0.017)\end{array}$ & $\begin{array}{c}-0.024 * * * \\
(0.002)\end{array}$ & $\begin{array}{l}-0.057 \\
(0.068)\end{array}$ & $\begin{array}{l}-0.013 \\
(0.016)\end{array}$ \\
\hline Age 60-64 & $\begin{array}{c}-0.241^{* * *} \\
(0.020)\end{array}$ & $\begin{array}{c}-0.030 * * * \\
(0.002)\end{array}$ & $\begin{array}{l}-0.075 \\
(0.072)\end{array}$ & $\begin{array}{l}-0.017 \\
(0.017)\end{array}$ \\
\hline Age 65-69 & $\begin{array}{c}-0.352 * * * \\
(0.024)\end{array}$ & $\begin{array}{c}-0.043^{* * *} \\
(0.003)\end{array}$ & $\begin{array}{l}-0.136 \\
(0.084)\end{array}$ & $\begin{array}{l}-0.031 \\
(0.020)\end{array}$ \\
\hline Age 70-74 & $\begin{array}{c}-0.410^{* * *} \\
(0.028)\end{array}$ & $\begin{array}{c}-0.050 * * * \\
(0.003)\end{array}$ & $\begin{array}{c}-0.224^{* *} \\
(0.100)\end{array}$ & $\begin{array}{c}-0.052^{* *} \\
(0.023)\end{array}$ \\
\hline Age 75-79 & $\begin{array}{c}-0.498 * * * \\
(0.031)\end{array}$ & $\begin{array}{c}-0.061^{* * *} \\
(0.004)\end{array}$ & $\begin{array}{l}-0.140 \\
(0.110)\end{array}$ & $\begin{array}{l}-0.033 \\
(0.025)\end{array}$ \\
\hline Age 80+ & $\begin{array}{c}-0.682 * * * \\
(0.032)\end{array}$ & $\begin{array}{c}-0.084^{* * *} \\
(0.004)\end{array}$ & $\begin{array}{l}-0.226^{*} \\
(0.116)\end{array}$ & $\begin{array}{l}-0.052 * \\
(0.027)\end{array}$ \\
\hline 50-100\% Poverty & $-0.048 *$ & $-0.006^{*}$ & $-0.190 * *$ & $-0.044 * *$ \\
\hline
\end{tabular}




\begin{tabular}{|c|c|c|c|c|}
\hline & $(0.026)$ & $(0.003)$ & $(0.074)$ & $(0.017)$ \\
\hline \multirow[t]{2}{*}{ 100-200\% Poverty } & $-0.267 * * *$ & $-0.033 * * *$ & $-0.458 * * *$ & $-0.106 * * *$ \\
\hline & $(0.024)$ & $(0.003)$ & $(0.071)$ & $(0.016)$ \\
\hline \multirow[t]{2}{*}{ >200\% Poverty } & $-0.924 * * *$ & $-0.114 * * *$ & $-1.081 * * *$ & $-0.250 * * *$ \\
\hline & $(0.024)$ & $(0.003)$ & $(0.077)$ & $(0.017)$ \\
\hline \multirow[t]{2}{*}{ Missing Income } & $-0.812 * * *$ & $-0.100 * * *$ & $-0.862 * * *$ & $-0.200 * * *$ \\
\hline & $(0.026)$ & $(0.003)$ & $(0.077)$ & $(0.017)$ \\
\hline \multirow[t]{2}{*}{ Homeowner } & $-0.364 * * *$ & $-0.045 * * *$ & $-0.318 * * *$ & $-0.074 * * *$ \\
\hline & $(0.012)$ & $(0.001)$ & $(0.044)$ & $(0.010)$ \\
\hline \multirow[t]{2}{*}{ Non-Metro } & -0.002 & -0.000 & -0.065 & -0.015 \\
\hline & $(0.012)$ & $(0.001)$ & $(0.043)$ & $(0.010)$ \\
\hline \multirow[t]{2}{*}{ Retired } & $-0.066 * * *$ & $-0.008 * * *$ & -0.033 & -0.008 \\
\hline & $(0.018)$ & $(0.002)$ & $(0.062)$ & $(0.014)$ \\
\hline \multirow[t]{2}{*}{ Unemployed } & $0.505^{* * *}$ & $0.062 * * *$ & $0.333 * * *$ & $0.077 * * *$ \\
\hline & $(0.023)$ & $(0.003)$ & $(0.089)$ & $(0.020)$ \\
\hline \multirow[t]{2}{*}{ Disabled } & $0.339 * * *$ & $0.042 * * *$ & $0.288 * * *$ & $0.067 * * *$ \\
\hline & $(0.013)$ & $(0.002)$ & $(0.046)$ & $(0.010)$ \\
\hline \multirow[t]{2}{*}{ Female } & 0.006 & 0.001 & -0.033 & -0.008 \\
\hline & $(0.010)$ & $(0.001)$ & $(0.040)$ & $(0.009)$ \\
\hline \multirow[t]{2}{*}{ South } & 0.009 & 0.001 & -0.021 & -0.005 \\
\hline & $(0.013)$ & $(0.002)$ & $(0.050)$ & $(0.012)$ \\
\hline \multirow[t]{2}{*}{ West } & -0.014 & -0.002 & -0.012 & -0.003 \\
\hline & $(0.015)$ & $(0.002)$ & $(0.059)$ & $(0.014)$ \\
\hline \multirow[t]{2}{*}{ Northeast } & $-0.065 * * *$ & $-0.008 * * *$ & -0.100 & -0.023 \\
\hline & $(0.015)$ & $(0.002)$ & $(0.064)$ & $(0.015)$ \\
\hline \multirow[t]{2}{*}{ Lives alone } & $-0.044 * * *$ & $-0.005^{* * *}$ & & \\
\hline & $(0.015)$ & $(0.002)$ & & \\
\hline
\end{tabular}

Wald Test $\quad 108.398$

dof, p-value [31,0.00]

Observations $252803 \quad 252803$

Robust standard errors in parentheses. ${ }^{* * *} \mathrm{p}<0.01$, ** $\mathrm{p}<0.05$, * $\mathrm{p}<0.1$ 
Table 5. Estimated Determinants of Very Low Food Security Rates among Adults Age 40+ by Presence of Grandchildren

\begin{tabular}{|c|c|c|c|c|}
\hline & \multicolumn{2}{|c|}{ No Grandchildren } & \multicolumn{2}{|c|}{ With Grandchildren } \\
\hline & Coefficients & Marginal Effects & Coefficients & Marginal Effects \\
\hline Constant & $\begin{array}{c}-1.106^{* * *} \\
(0.047)\end{array}$ & & $\begin{array}{c}-0.874 * * * \\
(0.175)\end{array}$ & \\
\hline African American & $\begin{array}{c}0.147 * * * \\
(0.021)\end{array}$ & $\begin{array}{c}0.008 * * * \\
(0.001)\end{array}$ & $\begin{array}{c}0.176^{* * *} \\
(0.065)\end{array}$ & $\begin{array}{c}0.017 * * * \\
(0.006)\end{array}$ \\
\hline Other Race & $\begin{array}{l}-0.001 \\
(0.031)\end{array}$ & $\begin{array}{l}-0.000 \\
(0.002)\end{array}$ & $\begin{array}{c}0.110 \\
(0.100)\end{array}$ & $\begin{array}{c}0.011 \\
(0.010)\end{array}$ \\
\hline Hispanic & $\begin{array}{l}-0.007 \\
(0.024)\end{array}$ & $\begin{array}{l}-0.000 \\
(0.001)\end{array}$ & $\begin{array}{l}-0.078 \\
(0.075)\end{array}$ & $\begin{array}{l}-0.008 \\
(0.007)\end{array}$ \\
\hline High School & $\begin{array}{c}-0.111^{* * *} \\
(0.019)\end{array}$ & $\begin{array}{c}-0.006^{* * *} \\
(0.001)\end{array}$ & $\begin{array}{l}-0.097 \\
(0.062)\end{array}$ & $\begin{array}{l}-0.010 \\
(0.006)\end{array}$ \\
\hline Some College & $\begin{array}{c}-0.053^{* *} \\
(0.021)\end{array}$ & $\begin{array}{c}-0.003^{* *} \\
(0.001)\end{array}$ & $\begin{array}{l}-0.092 \\
(0.076)\end{array}$ & $\begin{array}{l}-0.009 \\
(0.008)\end{array}$ \\
\hline College & $\begin{array}{c}-0.362 * * * \\
(0.026)\end{array}$ & $\begin{array}{c}-0.020^{* * *} \\
(0.001)\end{array}$ & $\begin{array}{c}0.163 \\
(0.102)\end{array}$ & $\begin{array}{c}0.016 \\
(0.010)\end{array}$ \\
\hline Married & $\begin{array}{c}-0.122 * * * \\
(0.024)\end{array}$ & $\begin{array}{c}-0.007 * * * \\
(0.001)\end{array}$ & $\begin{array}{l}-0.033 \\
(0.096)\end{array}$ & $\begin{array}{l}-0.003 \\
(0.009)\end{array}$ \\
\hline Widowed & $\begin{array}{c}0.123^{* * *} \\
(0.031)\end{array}$ & $\begin{array}{c}0.007 * * * \\
(0.002)\end{array}$ & $\begin{array}{c}0.101 \\
(0.115)\end{array}$ & $\begin{array}{c}0.010 \\
(0.011)\end{array}$ \\
\hline Divorced/Separated & $\begin{array}{c}0.204^{* * *} \\
(0.023)\end{array}$ & $\begin{array}{c}0.012^{* * *} \\
(0.001)\end{array}$ & $\begin{array}{c}0.128 \\
(0.099)\end{array}$ & $\begin{array}{c}0.013 \\
(0.010)\end{array}$ \\
\hline Age 44-49 & $\begin{array}{c}0.005 \\
(0.021)\end{array}$ & $\begin{array}{c}0.000 \\
(0.001)\end{array}$ & $\begin{array}{l}-0.049 \\
(0.092)\end{array}$ & $\begin{array}{l}-0.005 \\
(0.009)\end{array}$ \\
\hline Age $50-54$ & $\begin{array}{l}-0.016 \\
(0.022)\end{array}$ & $\begin{array}{c}-0.001 \\
(0.001)\end{array}$ & $\begin{array}{l}-0.018 \\
(0.090)\end{array}$ & $\begin{array}{l}-0.002 \\
(0.009)\end{array}$ \\
\hline Age 55-59 & $\begin{array}{c}-0.114^{* * *} \\
(0.024)\end{array}$ & $\begin{array}{c}-0.006^{* * *} \\
(0.001)\end{array}$ & $\begin{array}{l}-0.004 \\
(0.094)\end{array}$ & $\begin{array}{l}-0.000 \\
(0.009)\end{array}$ \\
\hline Age 60-64 & $\begin{array}{c}-0.167 * * * \\
(0.028)\end{array}$ & $\begin{array}{c}-0.009 * * * \\
(0.002)\end{array}$ & $\begin{array}{l}-0.131 \\
(0.103)\end{array}$ & $\begin{array}{l}-0.013 \\
(0.010)\end{array}$ \\
\hline Age 65-69 & $\begin{array}{c}-0.283^{* * *} \\
(0.034)\end{array}$ & $\begin{array}{c}-0.016^{* * *} \\
(0.002)\end{array}$ & $\begin{array}{c}-0.286^{* *} \\
(0.121)\end{array}$ & $\begin{array}{c}-0.028 * * \\
(0.012)\end{array}$ \\
\hline Age 70-74 & $\begin{array}{c}-0.387 * * * \\
(0.040)\end{array}$ & $\begin{array}{c}-0.022^{* * *} \\
(0.002)\end{array}$ & $\begin{array}{c}-0.440 * * * \\
(0.151)\end{array}$ & $\begin{array}{c}-0.044^{* * *} \\
(0.015)\end{array}$ \\
\hline Age 75-79 & $\begin{array}{c}-0.500 * * * \\
(0.045)\end{array}$ & $\begin{array}{c}-0.028 * * * \\
(0.003)\end{array}$ & $\begin{array}{c}-0.257^{*} \\
(0.153)\end{array}$ & $\begin{array}{l}-0.025^{*} \\
(0.015)\end{array}$ \\
\hline Age 80+ & $\begin{array}{c}-0.663^{* * *} \\
(0.047)\end{array}$ & $\begin{array}{c}-0.038 * * * \\
(0.003)\end{array}$ & $\begin{array}{c}-0.269 \\
(0.163)\end{array}$ & $\begin{array}{c}-0.027 \\
(0.016)\end{array}$ \\
\hline 50-100\% Poverty & $\begin{array}{l}-0.014 \\
(0.030)\end{array}$ & $\begin{array}{l}-0.001 \\
(0.002)\end{array}$ & $\begin{array}{c}-0.232^{* * *} \\
(0.089)\end{array}$ & $\begin{array}{c}-0.023^{* * *} \\
(0.009)\end{array}$ \\
\hline
\end{tabular}




\begin{tabular}{|c|c|c|c|c|}
\hline 100-200\% Poverty & $\begin{array}{c}-0.239 * * * \\
(0.029)\end{array}$ & $\begin{array}{c}-0.014 * * * \\
(0.002)\end{array}$ & $\begin{array}{c}-0.549 * * * \\
(0.089)\end{array}$ & $\begin{array}{c}-0.054 * * * \\
(0.009)\end{array}$ \\
\hline >200\% Poverty & $\begin{array}{c}-0.815^{* * *} \\
(0.030)\end{array}$ & $\begin{array}{c}-0.046 * * * \\
(0.002)\end{array}$ & $\begin{array}{c}-1.048 * * * \\
(0.101)\end{array}$ & $\begin{array}{c}-0.104 * * * \\
(0.010)\end{array}$ \\
\hline Missing Income & $\begin{array}{c}-0.725^{* * *} \\
(0.033)\end{array}$ & $\begin{array}{c}-0.041 * * * \\
(0.002)\end{array}$ & $\begin{array}{c}-0.802^{* * *} \\
(0.099)\end{array}$ & $\begin{array}{c}-0.079 * * * \\
(0.010)\end{array}$ \\
\hline Homeowner & $\begin{array}{c}-0.340 * * * \\
(0.016)\end{array}$ & $\begin{array}{c}-0.019 * * * \\
(0.001)\end{array}$ & $\begin{array}{c}-0.288 * * * \\
(0.061)\end{array}$ & $\begin{array}{c}-0.029 * * * \\
(0.006)\end{array}$ \\
\hline Non-Metro & $\begin{array}{c}-0.056^{* * *} \\
(0.017)\end{array}$ & $\begin{array}{c}-0.003 * * * \\
(0.001)\end{array}$ & $\begin{array}{c}-0.176^{* * *} \\
(0.061)\end{array}$ & $\begin{array}{c}-0.017^{* * *} \\
(0.006)\end{array}$ \\
\hline Retired & $\begin{array}{l}-0.021 \\
(0.026)\end{array}$ & $\begin{array}{l}-0.001 \\
(0.001)\end{array}$ & $\begin{array}{c}0.146 \\
(0.090)\end{array}$ & $\begin{array}{c}0.014 \\
(0.009)\end{array}$ \\
\hline Unemployed & $\begin{array}{c}0.496 * * * \\
(0.029)\end{array}$ & $\begin{array}{c}0.028 * * * \\
(0.002)\end{array}$ & $\begin{array}{c}0.302^{* * *} \\
(0.109)\end{array}$ & $\begin{array}{c}0.030 * * * \\
(0.011)\end{array}$ \\
\hline Disabled & $\begin{array}{c}0.366^{* * *} \\
(0.018)\end{array}$ & $\begin{array}{c}0.021^{* * *} \\
(0.001)\end{array}$ & $\begin{array}{c}0.106 \\
(0.066)\end{array}$ & $\begin{array}{c}0.010 \\
(0.007)\end{array}$ \\
\hline Female & $\begin{array}{l}-0.000 \\
(0.014)\end{array}$ & $\begin{array}{l}-0.000 \\
(0.001)\end{array}$ & $\begin{array}{c}0.032 \\
(0.057)\end{array}$ & $\begin{array}{c}0.003 \\
(0.006)\end{array}$ \\
\hline South & $\begin{array}{l}-0.001 \\
(0.018)\end{array}$ & $\begin{array}{l}-0.000 \\
(0.001)\end{array}$ & $\begin{array}{c}0.068 \\
(0.070)\end{array}$ & $\begin{array}{c}0.007 \\
(0.007)\end{array}$ \\
\hline West & $\begin{array}{l}-0.023 \\
(0.020)\end{array}$ & $\begin{array}{l}-0.001 \\
(0.001)\end{array}$ & $\begin{array}{c}0.125 \\
(0.080)\end{array}$ & $\begin{array}{c}0.012 \\
(0.008)\end{array}$ \\
\hline Northeast & $\begin{array}{c}-0.043^{* *} \\
(0.021)\end{array}$ & $\begin{array}{c}-0.002 * * \\
(0.001)\end{array}$ & $\begin{array}{l}-0.013 \\
(0.088)\end{array}$ & $\begin{array}{l}-0.001 \\
(0.009)\end{array}$ \\
\hline Lives alone & $\begin{array}{c}0.095^{* * *} \\
(0.020)\end{array}$ & $\begin{array}{c}0.005^{* * *} \\
(0.001)\end{array}$ & & \\
\hline
\end{tabular}

Wald Test

166.28

dof, p-value

[31,0.00]

Observations

252803

252803

10299

10299

Robust standard errors in parentheses. ${ }^{* * *} \mathrm{p}<0.01$, ** $\mathrm{p}<0.05,{ }^{*} \mathrm{p}<0.1$ 
Table 6. Predicted Risk Profiles of Food Insecurity (Percent)

Profile is an adult who is white, employed, married, ages 60-64, college educated, and living in metro area

\begin{tabular}{|c|c|c|c|c|c|c|}
\hline & \multicolumn{2}{|c|}{ Marginal Food Insecurity } & \multicolumn{2}{|c|}{ Food Insecurity } & \multicolumn{2}{|c|}{ Very Low Food Security } \\
\hline & $\begin{array}{c}\text { No } \\
\text { Grandchildren }\end{array}$ & $\begin{array}{c}\text { Grandchildren } \\
\text { Present }\end{array}$ & $\begin{array}{c}\text { No } \\
\text { Grandchildren }\end{array}$ & $\begin{array}{c}\text { Grandchildren } \\
\text { Present }\end{array}$ & $\begin{array}{c}\text { No } \\
\text { Grandchildren }\end{array}$ & $\begin{array}{c}\text { Grandchildren } \\
\text { Present }\end{array}$ \\
\hline \multicolumn{7}{|l|}{ Income } \\
\hline$<50 \%$ Poverty & 24.9 & 54.9 & 14.1 & 34.0 & 5.2 & 21.8 \\
\hline 50-100\% Poverty & 24.8 & 52.1 & 12.6 & 28.7 & 5.1 & 14.5 \\
\hline 100-200\% Poverty & 18.0 & 39.3 & 8.6 & 20.3 & 3.1 & 8.4 \\
\hline > 200\% Poverty & 4.7 & 17.1 & 2.2 & 7.3 & 0.7 & 3.0 \\
\hline \multicolumn{7}{|c|}{ Profile is an adult who is African American, disabled, female, divorced, ages 45-49, high school graduate, and living in metro area } \\
\hline & \multicolumn{2}{|c|}{ Marginal Food Insecurity } & \multicolumn{2}{|c|}{ Food Insecurity } & \multicolumn{2}{|c|}{ Very Low Food Security } \\
\hline & $\begin{array}{c}\text { No } \\
\text { Grandchildren }\end{array}$ & $\begin{array}{c}\text { Grandchildren } \\
\text { Present } \\
\end{array}$ & $\begin{array}{c}\text { No } \\
\text { Grandchildren }\end{array}$ & $\begin{array}{c}\text { Grandchildren } \\
\text { Present } \\
\end{array}$ & $\begin{array}{c}\text { No } \\
\text { Grandchildren }\end{array}$ & $\begin{array}{c}\text { Grandchildren } \\
\text { Present } \\
\end{array}$ \\
\hline \multicolumn{7}{|l|}{ Income } \\
\hline$<50 \%$ Poverty & 80.2 & 86.9 & 66.2 & 70.7 & 35.7 & 30.8 \\
\hline 50-100\% Poverty & 81.3 & 82.5 & 64.5 & 63.5 & 35.2 & 23.2 \\
\hline 100-200\% Poverty & 74.4 & 72.9 & 56.0 & 53.0 & 27.3 & 14.6 \\
\hline > 200\% Poverty & 45.8 & 47.2 & 30.6 & 29.2 & 11.9 & 6.1 \\
\hline
\end{tabular}


Table 7. The Determinants of Entry into and Exit from Food Insecurity

\begin{tabular}{|c|c|c|c|c|}
\hline & \multicolumn{2}{|c|}{ Entry } & \multicolumn{2}{|c|}{ Exit } \\
\hline & (1) & (2) & (3) & (4) \\
\hline VARIABLES & FFS to MFI & FFS to FI & MFI to FFS & FI to FFS \\
\hline \multicolumn{5}{|l|}{ Year 1 Values } \\
\hline Below Federal Poverty Line & $\begin{array}{c}0.159 * * * \\
(0.009)\end{array}$ & $\begin{array}{c}0.098^{* * *} \\
(0.008)\end{array}$ & $\begin{array}{c}-0.188^{* * *} \\
(0.009)\end{array}$ & $\begin{array}{c}-0.195^{* * *} \\
(0.013)\end{array}$ \\
\hline African American & $\begin{array}{c}0.058^{* * *} \\
(0.004)\end{array}$ & $\begin{array}{c}0.035^{* * *} \\
(0.003)\end{array}$ & $\begin{array}{c}0.005 \\
(0.009)\end{array}$ & $\begin{array}{c}0.026^{* *} \\
(0.013)\end{array}$ \\
\hline Other Race & $\begin{array}{c}0.006^{*} \\
(0.004)\end{array}$ & $\begin{array}{l}0.005^{*} \\
(0.003)\end{array}$ & $\begin{array}{c}0.014 \\
(0.013)\end{array}$ & $\begin{array}{c}0.014 \\
(0.019)\end{array}$ \\
\hline Hispanic & $\begin{array}{c}0.058 * * * \\
(0.004)\end{array}$ & $\begin{array}{c}0.042 * * * \\
(0.004)\end{array}$ & $\begin{array}{c}0.011 \\
(0.010)\end{array}$ & $\begin{array}{c}0.051^{* * *} \\
(0.015)\end{array}$ \\
\hline Age & $\begin{array}{c}-0.001^{* * *} \\
(0.000)\end{array}$ & $\begin{array}{c}-0.001^{* * *} \\
(0.000)\end{array}$ & $\begin{array}{c}0.003^{* * *} \\
(0.000)\end{array}$ & $\begin{array}{c}0.003^{* * *} \\
(0.001)\end{array}$ \\
\hline Female & $\begin{array}{l}-0.001 \\
(0.001)\end{array}$ & $\begin{array}{c}-0.002 * * \\
(0.001)\end{array}$ & $\begin{array}{c}-0.022^{* * *} \\
(0.007)\end{array}$ & $\begin{array}{c}-0.029 * * * \\
(0.010)\end{array}$ \\
\hline High School & $\begin{array}{c}-0.037 * * * \\
(0.003)\end{array}$ & $\begin{array}{c}-0.021^{* * *} \\
(0.002)\end{array}$ & $\begin{array}{c}0.024^{* * *} \\
(0.008)\end{array}$ & $\begin{array}{c}0.029 * * \\
(0.012)\end{array}$ \\
\hline Some College & $\begin{array}{c}-0.051^{* * *} \\
(0.003)\end{array}$ & $\begin{array}{c}-0.024 * * * \\
(0.002)\end{array}$ & $\begin{array}{c}0.026^{* * * *} \\
(0.009)\end{array}$ & $\begin{array}{c}0.015 \\
(0.014)\end{array}$ \\
\hline College & $\begin{array}{c}-0.077 * * * \\
(0.003)\end{array}$ & $\begin{array}{c}-0.038 * * * \\
(0.002)\end{array}$ & $\begin{array}{c}0.054^{* * *} \\
(0.012)\end{array}$ & $\begin{array}{c}0.038 * * \\
(0.018)\end{array}$ \\
\hline Married & $\begin{array}{c}-0.019 * * * \\
(0.003)\end{array}$ & $\begin{array}{c}-0.012 * * * \\
(0.002)\end{array}$ & $\begin{array}{c}0.026 * * \\
(0.011)\end{array}$ & $\begin{array}{c}0.006 \\
(0.016)\end{array}$ \\
\hline Widowed & $\begin{array}{c}0.010^{* *} \\
(0.004)\end{array}$ & $\begin{array}{c}0.002 \\
(0.003)\end{array}$ & $\begin{array}{c}0.001 \\
(0.014)\end{array}$ & $\begin{array}{l}-0.019 \\
(0.021)\end{array}$ \\
\hline Divorced/Separated & $\begin{array}{c}0.022 * * * \\
(0.004)\end{array}$ & $\begin{array}{c}0.011^{* * *} \\
(0.003)\end{array}$ & $\begin{array}{c}-0.046^{* * *} \\
(0.011)\end{array}$ & $\begin{array}{c}-0.056^{* * *} \\
(0.016)\end{array}$ \\
\hline Family Size & $\begin{array}{c}0.009 * * * \\
(0.001)\end{array}$ & $\begin{array}{c}0.005^{* * *} \\
(0.001)\end{array}$ & $\begin{array}{l}-0.000 \\
(0.002)\end{array}$ & $\begin{array}{c}0.002 \\
(0.003)\end{array}$ \\
\hline Retired & $\begin{array}{c}0.010^{* * *} \\
(0.002)\end{array}$ & $\begin{array}{c}0.008 * * * \\
(0.001)\end{array}$ & $\begin{array}{c}-0.055^{* * *} \\
(0.013)\end{array}$ & $\begin{array}{c}-0.076 * * * \\
(0.019)\end{array}$ \\
\hline Unemployed & $\begin{array}{c}0.075 * * * \\
(0.008)\end{array}$ & $\begin{array}{c}0.047 * * * \\
(0.006)\end{array}$ & $\begin{array}{c}-0.119 * * * \\
(0.016)\end{array}$ & $\begin{array}{c}-0.123 * * * \\
(0.022)\end{array}$ \\
\hline Disabled & $\begin{array}{c}0.046 * * * \\
(0.003)\end{array}$ & $\begin{array}{c}0.031^{* * *} \\
(0.002)\end{array}$ & $\begin{array}{c}-0.129 * * * \\
(0.009)\end{array}$ & $\begin{array}{c}-0.132 * * * \\
(0.012)\end{array}$ \\
\hline Homeowner & $\begin{array}{c}-0.062^{* * *} \\
(0.003)\end{array}$ & $\begin{array}{c}-0.037 * * * \\
(0.002)\end{array}$ & $\begin{array}{c}0.055^{* * *} \\
(0.007)\end{array}$ & $\begin{array}{c}0.060 * * * \\
(0.010)\end{array}$ \\
\hline Non-Metro & $\begin{array}{c}0.004^{* * *} \\
(0.002)\end{array}$ & $\begin{array}{l}-0.001 \\
(0.001)\end{array}$ & $\begin{array}{l}-0.007 \\
(0.007)\end{array}$ & $\begin{array}{l}-0.021^{*} \\
(0.011)\end{array}$ \\
\hline
\end{tabular}




\begin{tabular}{|c|c|c|c|c|}
\hline \multirow[t]{2}{*}{ South } & 0.002 & $0.003 * *$ & 0.009 & $0.037 * *$ \\
\hline & $(0.002)$ & $(0.002)$ & $(0.011)$ & $(0.016)$ \\
\hline \multirow[t]{2}{*}{ West } & 0.002 & 0.002 & 0.001 & 0.012 \\
\hline & $(0.002)$ & $(0.001)$ & $(0.010)$ & $(0.015)$ \\
\hline \multirow[t]{2}{*}{ Northeast } & 0.002 & 0.000 & 0.009 & $0.031 * *$ \\
\hline & $(0.002)$ & $(0.001)$ & $(0.010)$ & $(0.015)$ \\
\hline \multirow[t]{2}{*}{ State Unemployment Rate } & 0.001 & $0.0012^{* *}$ & 0.002 & 0.007 \\
\hline & $(0.001)$ & $(0.0006)$ & $(0.004)$ & $(0.006)$ \\
\hline \multirow[t]{2}{*}{ State Employment per capita } & $-0.069 * *$ & -0.025 & -0.221 & -0.040 \\
\hline & $(0.034)$ & $(0.024)$ & $(0.157)$ & $(0.230)$ \\
\hline \multicolumn{5}{|l|}{ Changes from Year 1 to Year 2} \\
\hline \multirow[t]{2}{*}{ Grandchild Enters Household } & $0.058 * * *$ & $0.040 * * *$ & $-0.097 * * *$ & $-0.069 * *$ \\
\hline & $(0.010)$ & $(0.008)$ & $(0.024)$ & $(0.033)$ \\
\hline \multirow[t]{2}{*}{ Grandchild Exits Household } & 0.017 & $0.019 * *$ & -0.031 & 0.010 \\
\hline & $(0.011)$ & $(0.009)$ & $(0.026)$ & $(0.038)$ \\
\hline \multirow[t]{2}{*}{ Grandchild Present Both Years } & $0.043^{* * *}$ & $0.015^{* * *}$ & $-0.023^{*}$ & -0.009 \\
\hline & $(0.006)$ & $(0.005)$ & $(0.014)$ & $(0.019)$ \\
\hline \multirow[t]{2}{*}{ Enter Marriage } & -0.008 & $-0.019 * *$ & $0.065^{*}$ & $0.117^{* *}$ \\
\hline & $(0.012)$ & $(0.007)$ & $(0.037)$ & $(0.051)$ \\
\hline \multirow[t]{2}{*}{ Exit Marriage } & $0.031 * * *$ & $0.027 * * *$ & $-0.083^{* * *}$ & $-0.093 * *$ \\
\hline & $(0.008)$ & $(0.006)$ & $(0.028)$ & $(0.040)$ \\
\hline \multirow[t]{2}{*}{ Enter Employment } & $-0.018 * * *$ & $-0.017 * * *$ & $0.080 * * *$ & $0.094 * * *$ \\
\hline & $(0.005)$ & $(0.004)$ & $(0.017)$ & $(0.024)$ \\
\hline \multirow[t]{2}{*}{ Exit Employment } & $0.045^{* * *}$ & $0.032 * * *$ & $-0.097 * * *$ & $-0.090 * * *$ \\
\hline & $(0.004)$ & $(0.003)$ & $(0.014)$ & $(0.020)$ \\
\hline \multirow[t]{2}{*}{ Enter Poverty } & $0.147 * * *$ & $0.101^{* * *}$ & $-0.150 * * *$ & $-0.163^{* * *}$ \\
\hline & $(0.007)$ & $(0.006)$ & $(0.012)$ & $(0.017)$ \\
\hline \multirow[t]{2}{*}{ Exit Poverty } & $-0.100 * * *$ & $-0.061 * * *$ & $0.106^{* * *}$ & $0.119 * * *$ \\
\hline & $(0.011)$ & $(0.009)$ & $(0.013)$ & $(0.017)$ \\
\hline \multirow[t]{2}{*}{ Change in State Unemployment Rate } & 0.003 & 0.001 & -0.007 & -0.015 \\
\hline & $(0.002)$ & $(0.001)$ & $(0.008)$ & $(0.012)$ \\
\hline \multirow[t]{2}{*}{ Change in State Employment per capita } & 0.206 & 0.199 & -0.836 & -0.716 \\
\hline & $(0.186)$ & $(0.132)$ & $(0.897)$ & $(1.311)$ \\
\hline \multirow[t]{2}{*}{ Constant } & $0.245^{* * *}$ & $0.127 * * *$ & $0.380 * * *$ & 0.239 \\
\hline & $(0.022)$ & $(0.016)$ & $(0.100)$ & $(0.147)$ \\
\hline Observations & 140487 & 134849 & 23290 & 10517 \\
\hline
\end{tabular}

All regressions control for time effects. Robust standard errors in parentheses. ${ }^{* * *} \mathrm{p}<0.01,{ }^{* *} \mathrm{p}<0.05,{ }^{*} \mathrm{p}<0.1$ FFS=Fully Food Secure; MFI=Marginally Food Insecure; FI=Food Insecure 
Table 8. The Determinants of Entry and Exit using Mutually Exclusive Food Security Categories

\begin{tabular}{|c|c|c|c|c|c|c|}
\hline & \multicolumn{3}{|c|}{ Entry Models } & \multicolumn{3}{|c|}{ Exit Models } \\
\hline VARIABLES & $\begin{array}{l}(1) \\
\text { FFS to } \\
\text { MFS }\end{array}$ & $\begin{array}{c}(2) \\
\text { MFS to } \\
\text { LFS }\end{array}$ & $\begin{array}{c}(3) \\
\text { LFS to } \\
\text { VLFS }\end{array}$ & $\begin{array}{l}(4) \\
\text { MFS to } \\
\text { FFS }\end{array}$ & $\begin{array}{c}(5) \\
\text { LFS to } \\
\text { MFS }\end{array}$ & $\begin{array}{c}(6) \\
\text { VLFS to } \\
\text { LFS }\end{array}$ \\
\hline Year 1 Values & & & & & & \\
\hline Below Federal Poverty Line & $\begin{array}{c}0.104 * * * \\
(0.008)\end{array}$ & $\begin{array}{c}0.081^{* * *} \\
(0.025)\end{array}$ & $\begin{array}{c}0.033 \\
(0.022)\end{array}$ & $\begin{array}{c}-0.111^{* * *} \\
(0.019)\end{array}$ & $\begin{array}{c}-0.056^{* *} \\
(0.022)\end{array}$ & $\begin{array}{c}-0.072^{* * *} \\
(0.024)\end{array}$ \\
\hline African American & $\begin{array}{c}0.032 * * * \\
(0.003)\end{array}$ & $\begin{array}{c}0.025 \\
(0.024)\end{array}$ & $\begin{array}{l}-0.033 \\
(0.022)\end{array}$ & $\begin{array}{c}0.006 \\
(0.015)\end{array}$ & $\begin{array}{l}-0.035 \\
(0.022)\end{array}$ & $\begin{array}{c}0.029 \\
(0.026)\end{array}$ \\
\hline Other Race & $\begin{array}{c}0.001 \\
(0.003)\end{array}$ & $\begin{array}{c}0.082^{* *} \\
(0.035)\end{array}$ & $\begin{array}{c}0.010 \\
(0.033)\end{array}$ & $\begin{array}{c}0.025 \\
(0.020)\end{array}$ & $\begin{array}{c}-0.100 * * * \\
(0.032)\end{array}$ & $\begin{array}{l}-0.010 \\
(0.037)\end{array}$ \\
\hline Hispanic & $\begin{array}{c}0.026 * * * \\
(0.004)\end{array}$ & $\begin{array}{c}-0.064^{* *} \\
(0.026)\end{array}$ & $\begin{array}{l}-0.026 \\
(0.025)\end{array}$ & $\begin{array}{c}-0.035^{* *} \\
(0.017)\end{array}$ & $\begin{array}{l}-0.003 \\
(0.025)\end{array}$ & $\begin{array}{c}0.073 * * \\
(0.031)\end{array}$ \\
\hline Age & $\begin{array}{c}-0.001^{* * *} \\
(0.000)\end{array}$ & $\begin{array}{c}-0.003^{* * *} \\
(0.001)\end{array}$ & $\begin{array}{l}-0.000 \\
(0.001)\end{array}$ & $\begin{array}{c}0.001^{* *} \\
(0.001)\end{array}$ & $\begin{array}{c}0.003^{* * *} \\
(0.001)\end{array}$ & $\begin{array}{c}0.003^{* *} \\
(0.001)\end{array}$ \\
\hline Female & $\begin{array}{c}0.001 \\
(0.001)\end{array}$ & $\begin{array}{c}0.011 \\
(0.017)\end{array}$ & $\begin{array}{l}-0.000 \\
(0.017)\end{array}$ & $\begin{array}{l}-0.010 \\
(0.010)\end{array}$ & $\begin{array}{l}-0.016 \\
(0.017)\end{array}$ & $\begin{array}{l}-0.025 \\
(0.019)\end{array}$ \\
\hline High School & $\begin{array}{c}-0.022^{* * *} \\
(0.003)\end{array}$ & $\begin{array}{l}-0.005 \\
(0.021)\end{array}$ & $\begin{array}{c}0.024 \\
(0.021)\end{array}$ & $\begin{array}{c}0.014 \\
(0.014)\end{array}$ & $\begin{array}{c}0.013 \\
(0.020)\end{array}$ & $\begin{array}{c}0.007 \\
(0.024)\end{array}$ \\
\hline Some College & $\begin{array}{c}-0.034^{* * *} \\
(0.003)\end{array}$ & $\begin{array}{c}0.012 \\
(0.024)\end{array}$ & $\begin{array}{c}0.032 \\
(0.024)\end{array}$ & $\begin{array}{c}0.021 \\
(0.015)\end{array}$ & $\begin{array}{c}0.004 \\
(0.023)\end{array}$ & $\begin{array}{l}-0.015 \\
(0.026)\end{array}$ \\
\hline College & $\begin{array}{c}-0.048^{* * *} \\
(0.003)\end{array}$ & $\begin{array}{l}-0.055^{*} \\
(0.029)\end{array}$ & $\begin{array}{l}-0.003 \\
(0.031)\end{array}$ & $\begin{array}{l}0.031^{*} \\
(0.017)\end{array}$ & $\begin{array}{c}0.018 \\
(0.030)\end{array}$ & $\begin{array}{l}-0.036 \\
(0.036)\end{array}$ \\
\hline Married & $\begin{array}{c}-0.008^{* * *} \\
(0.002)\end{array}$ & $\begin{array}{c}0.019 \\
(0.028)\end{array}$ & $\begin{array}{l}-0.043 \\
(0.027)\end{array}$ & $\begin{array}{l}0.035^{*} \\
(0.018)\end{array}$ & $\begin{array}{l}-0.000 \\
(0.027)\end{array}$ & $\begin{array}{l}-0.030 \\
(0.032)\end{array}$ \\
\hline Widowed & $\begin{array}{c}0.008 * * * \\
(0.003)\end{array}$ & $\begin{array}{c}0.045 \\
(0.036)\end{array}$ & $\begin{array}{l}-0.038 \\
(0.037)\end{array}$ & $\begin{array}{l}0.042 * \\
(0.023)\end{array}$ & $\begin{array}{l}-0.005 \\
(0.035)\end{array}$ & $\begin{array}{l}-0.059 \\
(0.040)\end{array}$ \\
\hline Divorced/Separated & $\begin{array}{c}0.014^{* * *} \\
(0.003)\end{array}$ & $\begin{array}{c}0.074 * * \\
(0.029)\end{array}$ & $\begin{array}{c}0.001 \\
(0.028)\end{array}$ & $\begin{array}{c}0.018 \\
(0.020)\end{array}$ & $\begin{array}{l}-0.027 \\
(0.027)\end{array}$ & $\begin{array}{c}-0.024 \\
(0.030)\end{array}$ \\
\hline Family Size & $\begin{array}{c}0.005^{* * *} \\
(0.001)\end{array}$ & $\begin{array}{c}0.006 \\
(0.006)\end{array}$ & $\begin{array}{c}-0.018^{* * *} \\
(0.005)\end{array}$ & $\begin{array}{c}0.003 \\
(0.004)\end{array}$ & $\begin{array}{l}-0.000 \\
(0.005)\end{array}$ & $\begin{array}{c}0.037 * * * \\
(0.007)\end{array}$ \\
\hline Retired & $\begin{array}{c}0.003^{*} \\
(0.002)\end{array}$ & $\begin{array}{c}0.011 \\
(0.030)\end{array}$ & $\begin{array}{c}0.025 \\
(0.032)\end{array}$ & $\begin{array}{c}-0.042 * * \\
(0.018)\end{array}$ & $\begin{array}{l}-0.017 \\
(0.031)\end{array}$ & $\begin{array}{l}-0.033 \\
(0.039)\end{array}$ \\
\hline Unemployed & $\begin{array}{c}0.040^{* * *} \\
(0.006)\end{array}$ & $\begin{array}{c}0.056 \\
(0.041)\end{array}$ & $\begin{array}{c}0.040 \\
(0.038)\end{array}$ & $\begin{array}{l}-0.040 \\
(0.027)\end{array}$ & $\begin{array}{c}0.010 \\
(0.036)\end{array}$ & $\begin{array}{l}-0.017 \\
(0.039)\end{array}$ \\
\hline Disabled & $\begin{array}{c}0.022 * * * \\
(0.003)\end{array}$ & $\begin{array}{c}0.011 \\
(0.022)\end{array}$ & $\begin{array}{c}0.054 * * \\
(0.021)\end{array}$ & $\begin{array}{c}-0.091^{* * *} \\
(0.015)\end{array}$ & $\begin{array}{l}-0.039 * \\
(0.021)\end{array}$ & $\begin{array}{c}-0.045^{*} \\
(0.024)\end{array}$ \\
\hline Homeowner & $\begin{array}{c}-0.035^{* * *} \\
(0.003)\end{array}$ & $\begin{array}{l}-0.033^{*} \\
(0.018)\end{array}$ & $\begin{array}{l}-0.020 \\
(0.018)\end{array}$ & $\begin{array}{c}0.016 \\
(0.012)\end{array}$ & $\begin{array}{c}0.019 \\
(0.017)\end{array}$ & $\begin{array}{c}0.004 \\
(0.020)\end{array}$ \\
\hline Non-Metro & $\begin{array}{c}0.005 * * * \\
(0.001)\end{array}$ & $\begin{array}{l}-0.015 \\
(0.018)\end{array}$ & $\begin{array}{l}-0.033^{*} \\
(0.018)\end{array}$ & $\begin{array}{l}-0.010 \\
(0.011)\end{array}$ & $\begin{array}{l}-0.023 \\
(0.018)\end{array}$ & $\begin{array}{c}0.018 \\
(0.021)\end{array}$ \\
\hline
\end{tabular}




\begin{tabular}{|c|c|c|c|c|c|c|}
\hline South & $\begin{array}{l}-0.001 \\
(0.002)\end{array}$ & $\begin{array}{c}0.009 \\
(0.027)\end{array}$ & $\begin{array}{l}-0.025 \\
(0.027)\end{array}$ & $\begin{array}{l}-0.003 \\
(0.016)\end{array}$ & $\begin{array}{c}0.078 * * * \\
(0.027)\end{array}$ & $\begin{array}{l}-0.003 \\
(0.031)\end{array}$ \\
\hline West & $\begin{array}{c}0.001 \\
(0.002)\end{array}$ & $\begin{array}{c}0.014 \\
(0.026)\end{array}$ & $\begin{array}{c}0.001 \\
(0.026)\end{array}$ & $\begin{array}{c}0.001 \\
(0.015)\end{array}$ & $\begin{array}{c}0.069 * * * \\
(0.025)\end{array}$ & $\begin{array}{l}-0.036 \\
(0.029)\end{array}$ \\
\hline Northeast & $\begin{array}{c}0.001 \\
(0.002)\end{array}$ & $\begin{array}{c}0.008 \\
(0.025)\end{array}$ & $\begin{array}{c}0.011 \\
(0.027)\end{array}$ & $\begin{array}{l}-0.010 \\
(0.015)\end{array}$ & $\begin{array}{l}0.044^{*} \\
(0.026)\end{array}$ & $\begin{array}{l}-0.017 \\
(0.028)\end{array}$ \\
\hline State Unemployment Rate & $\begin{array}{c}0.000 \\
(0.001)\end{array}$ & $\begin{array}{c}0.028 * * * \\
(0.010)\end{array}$ & $\begin{array}{l}-0.013 \\
(0.010)\end{array}$ & $\begin{array}{c}0.004 \\
(0.006)\end{array}$ & $\begin{array}{c}0.004 \\
(0.010)\end{array}$ & $\begin{array}{c}0.002 \\
(0.011)\end{array}$ \\
\hline State Employment per capita & $\begin{array}{l}-0.050 * \\
(0.028)\end{array}$ & $\begin{array}{c}0.460 \\
(0.393)\end{array}$ & $\begin{array}{l}-0.078 \\
(0.417)\end{array}$ & $\begin{array}{l}-0.398^{*} \\
(0.233)\end{array}$ & $\begin{array}{l}0.701^{*} \\
(0.408)\end{array}$ & $\begin{array}{l}-0.805^{*} \\
(0.455)\end{array}$ \\
\hline \multicolumn{7}{|l|}{ Changes from Year 1 to Year 2} \\
\hline Grandchild Enters Household & $\begin{array}{c}0.027 * * * \\
(0.008)\end{array}$ & $\begin{array}{c}0.080 \\
(0.056)\end{array}$ & $\begin{array}{l}-0.065 \\
(0.056)\end{array}$ & $\begin{array}{c}-0.100 * * \\
(0.045)\end{array}$ & $\begin{array}{c}0.018 \\
(0.054)\end{array}$ & $\begin{array}{c}0.164^{* *} \\
(0.065)\end{array}$ \\
\hline Grandchild Exits Household & $\begin{array}{c}0.000 \\
(0.008)\end{array}$ & $\begin{array}{c}0.092 \\
(0.064)\end{array}$ & $\begin{array}{c}0.138 * * \\
(0.070)\end{array}$ & $\begin{array}{c}0.001 \\
(0.042)\end{array}$ & $\begin{array}{c}0.095 \\
(0.066)\end{array}$ & $\begin{array}{l}-0.116 \\
(0.075)\end{array}$ \\
\hline Grandchild Present Both Years & $\begin{array}{c}0.036 * * * \\
(0.006)\end{array}$ & $\begin{array}{c}0.076 * * \\
(0.036)\end{array}$ & $\begin{array}{l}-0.023 \\
(0.029)\end{array}$ & $\begin{array}{l}-0.004 \\
(0.024)\end{array}$ & $\begin{array}{l}-0.054^{*} \\
(0.029)\end{array}$ & $\begin{array}{c}0.023 \\
(0.047)\end{array}$ \\
\hline Enter Marriage & $\begin{array}{c}0.011 \\
(0.010)\end{array}$ & $\begin{array}{l}-0.160 \\
(0.116)\end{array}$ & $\begin{array}{c}0.098 \\
(0.104)\end{array}$ & $\begin{array}{c}0.018 \\
(0.064)\end{array}$ & $\begin{array}{c}0.027 \\
(0.098)\end{array}$ & $\begin{array}{c}0.030 \\
(0.103)\end{array}$ \\
\hline Exit Marriage & $\begin{array}{c}0.007 \\
(0.006)\end{array}$ & $\begin{array}{c}0.073 \\
(0.072)\end{array}$ & $\begin{array}{c}0.006 \\
(0.067)\end{array}$ & $\begin{array}{l}-0.014 \\
(0.047)\end{array}$ & $\begin{array}{l}-0.046 \\
(0.066)\end{array}$ & $\begin{array}{l}-0.001 \\
(0.075)\end{array}$ \\
\hline Enter Employment & $\begin{array}{l}-0.004 \\
(0.004)\end{array}$ & $\begin{array}{l}-0.036 \\
(0.041)\end{array}$ & $\begin{array}{c}0.018 \\
(0.040)\end{array}$ & $\begin{array}{l}0.045^{*} \\
(0.027)\end{array}$ & $\begin{array}{c}0.016 \\
(0.039)\end{array}$ & $\begin{array}{c}0.046 \\
(0.047)\end{array}$ \\
\hline Exit Employment & $\begin{array}{c}0.019 * * * \\
(0.003)\end{array}$ & $\begin{array}{c}0.058^{*} \\
(0.034)\end{array}$ & $\begin{array}{c}0.109 * * * \\
(0.035)\end{array}$ & $\begin{array}{c}-0.068^{* * *} \\
(0.023)\end{array}$ & $\begin{array}{l}-0.023 \\
(0.034)\end{array}$ & $\begin{array}{l}-0.015 \\
(0.042)\end{array}$ \\
\hline Enter Poverty & $\begin{array}{c}0.078 * * * \\
(0.006)\end{array}$ & $\begin{array}{c}0.117 * * * \\
(0.031)\end{array}$ & $\begin{array}{c}0.061^{* *} \\
(0.029)\end{array}$ & $\begin{array}{c}-0.056 * * \\
(0.022)\end{array}$ & $\begin{array}{l}-0.027 \\
(0.028)\end{array}$ & $\begin{array}{l}-0.057 * \\
(0.031)\end{array}$ \\
\hline Exit Poverty & $\begin{array}{c}-0.073 * * * \\
(0.010)\end{array}$ & $\begin{array}{c}-0.144 * * * \\
(0.033)\end{array}$ & $\begin{array}{l}-0.004 \\
(0.030)\end{array}$ & $\begin{array}{c}0.032 \\
(0.025)\end{array}$ & $\begin{array}{c}0.010 \\
(0.030)\end{array}$ & $\begin{array}{c}0.095^{* * *} \\
(0.032)\end{array}$ \\
\hline Change in State & & & & & & \\
\hline Unemployment Rate & $\begin{array}{c}0.002 \\
(0.001)\end{array}$ & $\begin{array}{l}-0.006 \\
(0.020)\end{array}$ & $\begin{array}{c}0.027 \\
(0.021)\end{array}$ & $\begin{array}{l}-0.003 \\
(0.012)\end{array}$ & $\begin{array}{l}-0.035^{*} \\
(0.020)\end{array}$ & $\begin{array}{l}-0.002 \\
(0.023)\end{array}$ \\
\hline $\begin{array}{l}\text { Change in State Employment } \\
\text { per capita }\end{array}$ & $\begin{array}{c}0.046 \\
(0.150)\end{array}$ & $\begin{array}{c}1.931 \\
(2.159)\end{array}$ & $\begin{array}{c}0.509 \\
(2.122)\end{array}$ & $\begin{array}{l}-0.903 \\
(1.376)\end{array}$ & $\begin{array}{l}-0.658 \\
(2.142)\end{array}$ & $\begin{array}{l}-2.463 \\
(2.541)\end{array}$ \\
\hline Constant & $\begin{array}{c}0.144 * * * \\
(0.018)\end{array}$ & $\begin{array}{c}0.111 \\
(0.250)\end{array}$ & $\begin{array}{l}0.444 * \\
(0.266)\end{array}$ & $\begin{array}{c}0.833^{* * *} \\
(0.145)\end{array}$ & $\begin{array}{l}-0.093 \\
(0.250)\end{array}$ & $\begin{array}{l}0.504 * \\
(0.290)\end{array}$ \\
\hline Observations & 136405 & 3811 & 3322 & 8611 & 4062 & 2804 \\
\hline
\end{tabular}

All regressions control for time effects. Robust standard errors in parentheses. ${ }^{* * *} \mathrm{p}<0.01,{ }^{* *} \mathrm{p}<0.05,{ }^{*} \mathrm{p}<0.1$. FFS=Fully Food Secure, MFS=Marginally Food Secure, LFS=Low Food Insecure, VLFS=Very Low Food Secure 


\section{Appendix Table 1.}

Food Insecurity Questions in the Core Food Security Module

1. "We worried whether our food would run out before we got money to buy more." Was that often, sometimes, or never true for you in the last 12 months?

2. "The food that we bought just didn't last and we didn't have money to get more." Was that often, sometimes, or never true for you in the last 12 months?

3. "We couldn't afford to eat balanced meals." Was that often, sometimes, or never true for you in the last 12 months?

4. "We relied on only a few kinds of low-cost food to feed our children because we were running out of money to buy food." Was that often, sometimes, or never true for you in the last 12 months?

5. In the last 12 months, did you or other adults in the household ever cut the size of your meals or skip meals because there wasn't enough money for food? (Yes/No)

6. "We couldn't feed our children a balanced meal, because we couldn't afford that." Was that often, sometimes, or never true for you in the last 12 months?

7. In the last 12 months, did you ever eat less than you felt you should because there wasn't enough money for food? (Yes/No)

8. (If yes to Question 5) How often did this happen—almost every month, some months but not every month, or in only 1 or 2 months?

9. “The children were not eating enough because we just couldn't afford enough food.” Was that often, sometimes, or never true for you in the last 12 months?

10. In the last 12 months, were you ever hungry, but didn't eat, because you couldn't afford enough food? (Yes/No)

11. In the last 12 months, did you lose weight because you didn't have enough money for food? (Yes/No)

12. In the last 12 months, did you ever cut the size of any of the children's meals because there wasn't enough money for food? (Yes/No)

13. In the last 12 months did you or other adults in your household ever not eat for a whole day because there wasn't enough money for food? (Yes/No)

14. In the last 12 months, were the children ever hungry but you just couldn't afford more food? (Yes/No)

15. (If yes to Question 13) How often did this happen-almost every month, some months but not every month, or in only 1 or 2 months?

16. In the last 12 months, did any of the children ever skip a meal because there wasn't enough money for food? (Yes/No)

17. (If yes to Question 16) How often did this happen-almost every month, some months but not every month, or in only 1 or 2 months?

18. In the last 12 months did any of the children ever not eat for a whole day because there wasn't enough money for food? (Yes/No)

Notes: Responses in bold indicate an affirmative response. 
Appendix Table 2: Demographic Factors in Regression Models of Prevalence of Food Insecurity

Race

Ethnicity

Education

Marital Status

Age

Income Level

Housing Status

City Status

Employment Status

Gender

Region of Country

Family Structure
White (omitted)

African American

Other

Non-Hispanic (omitted)

Hispanic

High School Dropout (omitted)

High School Graduate

Some College

College Degree or more

Never Married (omitted)

Married

Widowed

Divorced/Separated

60-64 (omitted)

65-69

70-74

75-79

$80+$

Less than $50 \%$ of Poverty Line (omitted)

$50-100 \%$ of Poverty Line

$100-200 \%$ of Poverty Line

$>200 \%$ of Poverty Line Missing

Renter (omitted)

Homeowner

Live in Metro Area (omitted)

Live in Non-Metro Area

Employed (omitted)

Retired

Unemployed

Disabled

Male (omitted)

Female

Midwest (omitted)

South

West

Northeast

Lives with Others (omitted)

Lives Alone 